\title{
STUDIES ON MARINE ALGAE OF THE BRITISH ISLES: THE GENUS CERAMIUM
}

\author{
By Peter S. Dixon \\ Hartley Botanical Laboratories, The University, Liverpool 3
}

(Text-figs. I-15)

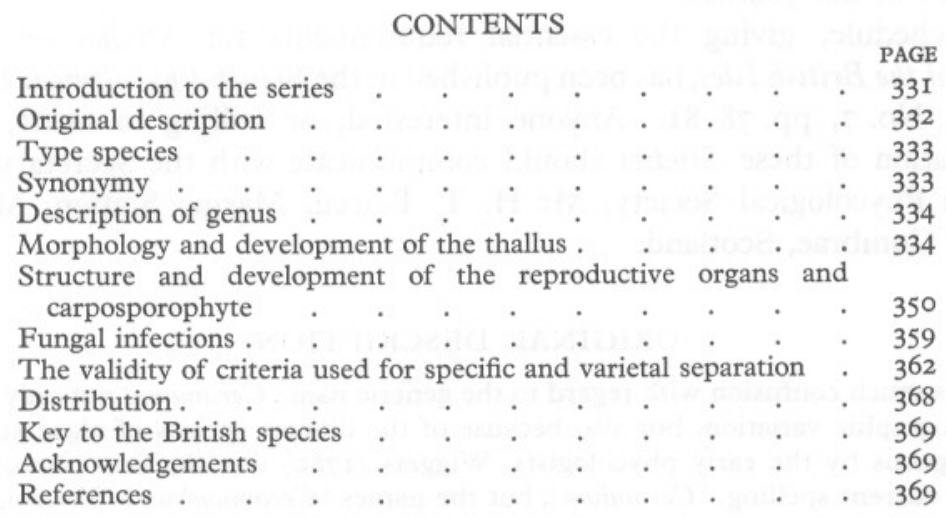

\section{INTRODUCTION TO THE SERIES}

The British Phycological Society was founded in 1952 to serve as a meetingground for phycologists, and to carry out a co-ordinated scheme of work on the algae of this country. The specific projects included the production of a Flora of British Marine Algae and the publication of a series of biological studies of individual genera and species.

It had been realized for some time that knowledge of the marine algae which occur on the coasts of the British Isles was very inadequate, and recent activities of the Society have made this increasingly obvious. Morphological data are based largely on static anatomical studies and there is little information available on developmental processes. The significance of the range of external form of the thallus in relation to differing conditions of season and environment has not been fully appreciated so that the limits of many genera and species are extremely ill-defined. There is, moreover, a lack of critical nomenclatural studies, with the result that the names currently applied to taxa are largely the result of tradition, whilst knowledge of their ecology and geographical distribution within the British Isles is very incomplete. 
It is hoped that the forthcoming publications of the British Phycological Society will help to resolve some of these problems. Work is progressing on the Flora of British Marine Algae. The first of the biological studies of individual genera and species is now being published. It is intended that this series of Studies on Marine Algae of the British Isles will provide a concise but comprehensive survey of taxonomy, nomenclature, morphology, reproduction, life history, ecology and distribution, with particular reference to the British representatives. Such Studies will supplement the descriptions, inevitably abbreviated, in the formal taxonomic treatment of the Flora of British Marine Algae. It is hoped that these Studies will be published at intervals in this fournal.

A schedule, giving the essential requirements for Studies on Marine Algae of the British Isles, has been published in the British Phycological Bulletin, Vol. I, No. 7, pp. 78-81. Anyone interested, or willing to assist, in the preparation of these Studies should communicate with the Secretary of the British Phycological Society, Mr H. T. Powell, Marine Station, Millport, Isle of Cumbrae, Scotland.

\section{ORIGINAL DESCRIPTION}

There is much confusion with regard to the generic name Ceramium, not only because of orthographic variation, but also because of the diverse species of algae attributed to the genus by the early phycologists. Wiggers (1780) was the first phycologist to use the current spelling, 'Ceramium', but the names 'Ceramion' and 'Keramion' used by Adanson ( 1763, pp. I3, (8), 535) are now regarded as orthographic variants of this.

The names Ceramion and Keramion were proposed by Adanson as a substitute for Ceramianthemum Donati ( 1758 ), now regarded as a synonym of Gracilaria Greville (1830). The diverse species attributed to the genus by later authors are as follows:

\begin{tabular}{|c|c|}
\hline Wiggers (I780) & $\begin{array}{l}\text { C. filum (= Chorda filum (L.) Stackh.) } \\
\text { C. fastigiatum (= Furcellaria fastigiata (L.) Lamour.) } \\
\text { C. furcellatum (= Furcellaria fastigiata (L.) Lamour.) } \\
\text { C. confervoides (= Gracilaria verrucosa (Huds.) Papenf.) }\end{array}$ \\
\hline Gaertner ( 1788$)$ & C. plumosum (= Ptilota plumosa (Huds.) Ag.) \\
\hline Stackhouse (I797) & $\begin{array}{l}\text { C. saccharinum (= Laminaria saccharina (L.) Lamour.) } \\
\text { C. bulbosum (= Saccorhiza polyschides (Lightf.) Batt.) } \\
\text { C. digitatum (= Laminaria digitata (Huds.) Lamour.) } \\
\text { C. edule (= Dilsea carnosa (Schmidel) Kuntze) } \\
\text { C. palmatum (= Rhodymenia palmata } \text { (L.) Grev.) } \\
\text { C. phyllitis (= Laminaria saccharina (L.) Lamour.) } \\
\text { C. esculentum (= Alaria esculenta } \text { (L.) Grev.) }\end{array}$ \\
\hline
\end{tabular}

Roth (1797) referred various species to the genus Ceramium and one of these, C. virgatum Roth, is a representative of the genus as now delimited. In addition to C. virgatum, Roth included in this, his first, treatment of the genus Ceramium species now referred to the genera Chorda, Polysiphonia, Ectocarpus and Vaucheria. Silva (I952) has given a full analysis of the early concepts of Ceramium and has argued quite rightly in favour of the conservation of Ceramium Roth. The existing grounds for 
conservation of Ceramium against Apona Adanson (1763) and Episperma Rafinesque (I8I4) were questionable, in that typification of Apona is a matter for conjecture whilst Episperma, in the absence of specimens or figures, cannot be typified at all. To clarify this situation, Silva proposed, first, that the problematical Apona could be suppressed by appropriate typification and by its acceptance as the nomen rejiciendum of Lemanea, and, secondly, that Ceramium Roth (1797) should be conserved against Ceramion Adanson (1763). These two proposals have now been accepted (see Lanjouw, I956, p. 206).

\title{
TYPE SPECIES
}

A type species for the genus was not designated by Roth. As Ceramium Roth(I797) contains but a single species of the genus as now delimited, Silva (I952) has proposed this species, $C$. virgatum Roth, as the lectotype species:

Ceramium virgatum Roth (1797, p. I48; pl. 8, fig. I)

[non Ceramium virgatum Hooker \& Harvey (I848, p. 445)]

= Ceramium rubrum (Huds.) Agardh (I8I I, p. I7), fide C. Agardh, loc. cit.

The earlier proposal by Schmitz (1889) of Ceramium rubrum as the type species, repeated by Kylin (1956), is incorrect in that Conferva rubra Hudson (1762), its basionym, is not listed as such by Roth in his original treatment of the genus.

Roth's herbarium was transferred from Oldenburg to the Botanisches Museum, Berlin, in 1930, and there destroyed by bombing in March I945 (Pilger, I953). A few Roth specimens are still in existence in other herbaria, but attempts to locate duplicate material of $C$. virgatum have proved unsuccessful. The figure of $C$. virgatum given by Roth (I797, pl. 8, fig. I) is not good, but it is sufficiently clear to permit identification; in the absence of a specimen this figure should be designated as the type of $C$. virgatum Roth.

\section{SYNONYMY}

\author{
Dictiderma Bonnemaison (I822, p. I85) \\ Hormoceras Kützing ( $184 \mathrm{I},{ }^{1}$ p. 730 ) \\ Gongroceras Kützing (I84I, ${ }^{1}$ p. 730) \\ Echinoceras Kützing (I84I, ${ }^{1}$ p. 73I) \\ Acanthoceras Kützing (I84I, ${ }^{1}$ p. $73 \mathrm{I}$ ) \\ Chaetoceras Kützing (I847, p. 34) \\ nec Chaetoceros Ehrenberg (I844, p. I98) \\ nec Chaetoceras Kützing (1849, p. 138) \\ Trichoceras Kützing (1849, p. 680) \\ Celeceras Kützing (I849, p. 683) \\ Pteroceras Kützing (I849, p. 690) \\ Ceramothamnion Richards (I90I, p. 257)
}

As Silva (I952) has commented, Bonnemaison (1822) was the first author to distinguish clearly between the species now attributed to the genera Ceramium and Polysiphonia, placing species of the former in his Dictiderma, for which Conferva rubra Huds. [ = Ceramium rubrum (Huds.) Ag.] was designated as the type species. In his

1 Kützing's paper 'Ueber Ceramium Ag.' is published in the last part of volume I5 of the journal Linnaea, which is dated I84I. Howe (1914, p. 155) has indicated, quite correctly, that Kützing (I849), in Species Algarum, consistently cites ' 1842 ' as the date of publication of this paper. Because of this, Howe has regarded 1842 as the true date of publication. Setchell \& Gardner (1924), on the other hand, have pointed out that in the earlier 'Phycologia Generalis' (Kützing, I843), 'I84I' is cited, equally consistently. Attempts to determine the precise date of publication have not been successful, so that at the present time it would seem best to retain the date of $\mathrm{I} 84 \mathrm{I}$ for this publication until further information is available. 
revision of the genus Ceramium, Kützing (I84I, I847, I849), in a series of proposals, suggested that the genus should be divided into nine smaller genera, viz. Hormoceras, Gongroceras, Echinoceras, Acanthoceras, Chaetoceras, Trichoceras, Celeceras, Pteroceras and Centroceras. Of these, only the last, Centroceras, has been retained by subsequent authors and this would appear to be well founded. The other proposals made by Kützing were not accepted generally at the time, possibly because of the constant changes of generic circumscription in the various publications and possibly because of the large number of very ill-defined species described by Kützing for these genera. By modern taxonomic standards there is no justification for the generic subdivision proposed by Kützing, other than the separation of Centroceras. The genus Ceramothamnion, proposed by Richards (I90I) for his new species $C$. codii, does not differ from Ceramium in any essential feature. Mazoyer (1938) refers Ceramothamnion codii to the genus Ceramium, rightly stating that there is no justification for the creation of a distinct genus for this species. This opinion has been repeated by this and other authors (Feldmann-Mazoyer, 1940, in Børgesen, 1952; Dixon, 1958), but it should be noted that Ceramothamnion was still retained by both Fritsch (I945) and Kylin (1956).

In addition to the synonyms cited above, Børgesen (1953) has recently proposed the new genus Ceramiella, for Ceramium huysmansii Weber v. Bosse (1923) and has suggested that the $C$. maryae of the same author might also be referable to this genus. Mme Feldmann has commented (in Børgesen, 1953) that in her opinion there is no justification for the creation of a distinct genus for C. huysmansii and that this species should be referred to Centroceras. At the present time, the morphological information on Ceramiella huysmansii is so inadequate that no decision as to the correct taxonomic position of this species can be made. Under the circumstances, Dawson (1954) has adopted the most logical attitude, by retaining both $C$. huysmansii and C. maryae in Ceramium, pending further study.

\section{DESCRIPTION OF GENUS}

Genus of marine and brackish waters.

Thallus of uniaxial construction, erect or prostrate, $0.1-30.0 \mathrm{~cm}$ in length, red, brown or purple in colour; axes filiform, $0 . \mathrm{I}-\mathrm{I} .5 \mathrm{~mm}$ in diameter, pseudo-dichotomously or irregularly branched, differentiated into axial cells and cortex; axial cells large (up to $1.5 \mathrm{~mm}$ in length), ovoid or cylindrical, hyaline or faintly pigmented; cortex formed by the aggregation of the filaments of limited growth, arranged in bands encircling the axial cells and forming a partial or complete investment.

Tetrasporangia borne laterally on filaments of limited growth, partially or completely embedded, tetrahedral or cruciate.

Sexual thalli dioecious, rarely monoecious; spermatangia hyaline, developing superficially from the ultimate cells of the lateral branches of limited growth, forming colourless patches of variable size on the surface of the cortex; carpogonial branches and auxiliary cells developing from the basal cells of the filaments of limited growth near to the apex of an axis; carposporophyte exserted, naked, sessile, subtended by a number of adventitious axes.

\section{MORPHOLOGY AND DEVELOPMENT OF THE THALLUS}

The thalli of all Florideae are built up by the aggregation of filaments, which result from the division of apical cells. Some of these filaments are of unlimited growth and form the axes of the thallus; the majority, however, are 


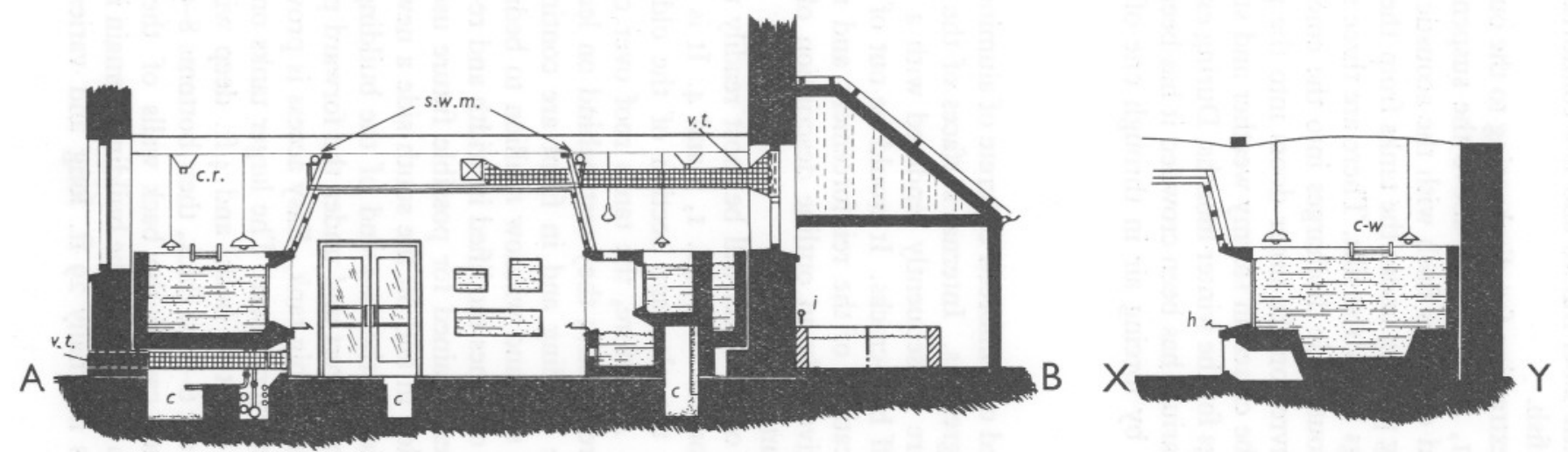

Fig. 2

Text-figs. I and 2. Plan and sections of the new aquarium and new outside circulation. Water in the exhibition tanks is indicated by line and dot stippling. $c$, sea-water return culvert; c.b., circulation bench; c.r., overhead conveyor rail (Henderson track); $c$-w, cat-walk; $h$, hand-rail; $i$, inflows; $o$, overflows; p.b., plunger bucket; $s$, sill; $s$-ww, swim-ways; s.w.m., sea-water main. 
in the sill, about $3 \mathrm{ft}$. above floor level and nearly $2 \mathrm{ft}$ from the glass, gives some protection to the latter and to the label frames and is a comfortable support to lean on whilst watching the fish.

The hall is ventilated by an extraction fan discharging to the outside at the north-west corner (Text-figs. I, 2). Trunking above the suspended ceiling draws air through three louvred openings flush with the acoustic tiling. Air enters the hall through trunking passing under the tanks from the outside of the building to louvred openings below the sills. There are three such trunks on each side, but one on the south side discharges into the emergency exit passage, and then through louvres on the inner doors into the public hall. Louvres on the south side can be closed in stormy weather and storm covers are fitted on the outside openings for the winter months. During exceptionally hot calm weather when the aquarium has been crowded it has been necessary to augment normal ventilation by forcing air in through one of the intake trunks on the north side.

\section{Basic construction of the tanks}

The new tanks are constructed of reinforced concrete of aluminous cement mixed with local sands and aggregates. Internal surfaces of the back walls and parts of the side walls were subsequently rendered with a waterproof cement and sand mix to seal off hair-cracks. It would be out of place here to give full engineering specifications of the reinforcement and methods of construction; it is feasible to give only an outline description of the tanks as they can be observed in a completed state.

The arrangement and shapes of the tanks will be most readily understood by a study of the plan and sections in Text-figs. I, 2 and 4 . It is instructive to compare these figures with the plan and section of the old aquarium (Wilson, 1952, text-figs. I, 2). As before, the tanks roof over culverts returning overflow water to the reservoirs; they rest behind on ledges at the bases of the main walls of the building and in front are continuous with concrete pillars extending each stile and window mullion to bedrock below floor level. The culverts are the old ones modified in width and re-asphalted. The old central culvert has been retained for possible future use. The old drainage trenches have been filled in and on the south side a new trench to carry services to the laboratories at the east end of the building has been excavated alongside the southern culvert and under the forward parts of the tanks. These services pass under the big tank. Easy access is provided to all culverts and to the service pipes everywhere. The larger tanks on the north and south sides are $6 \mathrm{ft}$. wide (front to back) and $4 \mathrm{ft}$. deep with a water depth of $3 \mathrm{ft}$. 6 in. Their walls are 6-7 in. thick, their bottoms $8-9$ in. thick. Creosoted soft-boards used when casting the back walls of the tanks, to prevent the concrete adhering to the walls of the building, remain in position. The big tank at the east end is internally $29 \mathrm{ft}$. long and varies in width 
from about $8 \mathrm{ft} .4$ in. at the centre to about $9 \mathrm{ft}$. 3 in. near each end. The bottom of this tank is about ro in. thick, and at the north end it drops down to a lower level over an area irregular in shape, thereby increasing the water depth at this place by about I ft. 3 in. The small tanks with a water depth of rather less than $2 \mathrm{ft}$. 6 in. occupy the corners between the ends of the big tank and the north- and south-side series. On the north side at the west end a shallow triangular tank overlaps a floor tank which is divisible into two with a removable partition or, as at present, by built-in rockwork. The floor tank is viewed only through the water surface and is designed for the display of flatfishes on contrasted bottom shingles. Except for this floor tank the water surface in all the tanks is at a uniform height, permitting openings to be made between tanks as described below (p. 402).

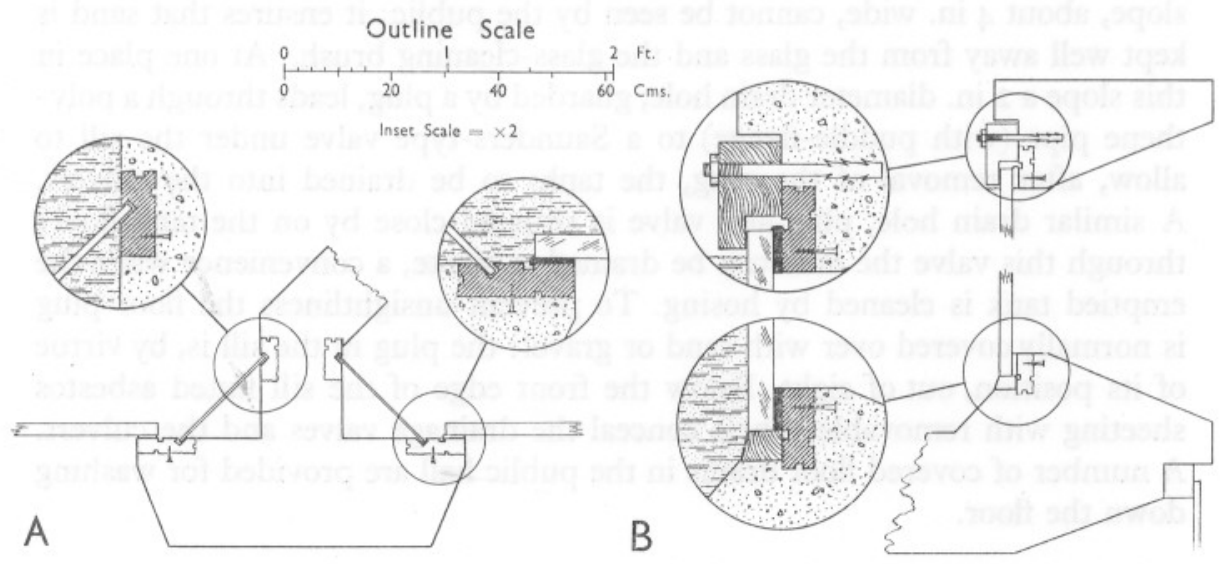

Text-fig. 3. A. Plan of a stile between a triangular tank on the right and a larger tank on the left, including a portion of the dividing wall with polythene sheets slid into slate slots to form inflow ducts. Inset are details of slotted slate inserts keyed to the concrete by grooving and rustless-steel screws. In the right inset is shown the edge of a glass pane with sealing compound ('Glasticon', drawn solid black) between it and the slate.

B. Section of a tank front showing lintel walk-way and sill. Inset above are details of teak turnbuckle on rustless-steel rag-bolt, top edge of glass, water level, etc. Inset below shows bottom edge of glass resting on teak block on ledge of sill with details of grooved slate inserts, sealing compound, etc.

Except for the shallower tanks all the window openings are of uniform size, $5 \mathrm{ft}$. $7 \frac{1}{2}$ in. long by $3 \mathrm{ft}$. high. One advantage of this uniformity is that a single spare pane of glass fits all tanks except the shallow ones. The glass panes, I in. thick, overlap the window opening $I \frac{1}{2}$ in. all round. These openings are formed of slate inserts keyed to the concrete (Text-fig. 3). The slates are grooved to give facings exactly $\mathrm{I} \frac{1}{2}$ in. wide. This is necessary to achieve uniformity of pressure on the sealing compound and to aid in positioning the glass. The glass is pressed by water pressure against the sealing compound 'Glasticon' ('Glasticord' 304) laid in strip form on the facings 
(for method of glazing see Wilson, 1952, p. 195). A single teak turnbuckle fixed to the frame above the middle top edge of each pane prevents accidental falling inwards of the glass when the tank is emptied.

The top edges of all window openings are $5 \mathrm{ft}$. 7 in. above floor level all round the aquarium. The heads or lintels are wide and flat topped, they carry the sloping sides of the suspended ceiling and form convenient walk-ways for servicing the tanks (Pl. II, fig. I), especially for glass-cleaning. The sills are also wide and carry externally the label frames and support the hand-rail already described. Within each tank the sill provides a ledge $I \frac{1}{2}$ in. wide on which the bottom edge of the glass pane rests, though indirectly with two teak blocks near either end between it and the concrete (Text-fig. 3). From this ledge the sill slopes downwards at $45^{\circ}$ to the tank floor (Text-fig. 4). This slope, about 4 in. wide, cannot be seen by the public; it ensures that sand is kept well away from the glass and the glass-cleaning brush. At one place in this slope a 2 in. diameter drain hole, guarded by a plug, leads through a polythene pipe (with puddle-flange) to a Saunders-type valve under the sill to allow, after removal of the plug, the tanks to be drained into the culvert. A similar drain hole, plug and valve is situated close by on the tank floor; through this valve the tank can be drained to waste, a convenience when the emptied tank is cleaned by hosing. To prevent unsightliness the floor plug is normally covered over with sand or gravel: the plug in the sill is, by virtue of its position, out of sight. Below the front edge of the sill fluted asbestos sheeting with removable panels conceal the drainage valves and the culvert. A number of covered floor drains in the public hall are provided for washing down the floor.

\section{Circulation}

At the time of writing the same two centrifugal pumps mentioned in a previous paper (Wilson, 1952, p. 204) maintain the circulation, but new pumps of larger capacity will be installed in the near future. The old 4 in. vulcanite main rising from the engine room in the north-west corner (Textfig. I) feeds into a new 3 in. black polythene ('Alkathene') pipe which divides into two branches, each controlled by a Saunders valve, one to the northside tanks and one to the south. These two mains run close to the true ceiling above the corner of the suspended ceiling (Text-figs. 2, 4); there they are readily accessible. Cleaning eyes are provided at bends where needed. From these high-level mains down-dropping $\mathrm{I}_{2} \frac{1}{2}$ in. pipes, also of black polythene and controlled by Saunders valves, lead through smaller branches to nozzles injecting water into the tanks (Text-figs. 4,5 and Pl. II, fig. I). In the old aquarium the mains lay along the tops of the tanks not far above water level and numerous nozzles injected water and air bubbles into the tanks. Not only were these mains an obstruction to servicing but the inflow method was inefficient, for only a portion of the water ever reached tank bottom and 




Text-fig. 4. Section through a north-side tank incorporating perspective view facing east and showing portions of three tanks and part of the public hall. Behind the tank is the main wall of the building with a window. The back of the tank rests on a footing of the wall, but indirectly on copper plates forming a sliding bearing to allow for possible movement; the plates are sealed from the sea-water circulation. Between the back wall of the tank and the wall of the building is a layer of creosoted soft-board which during construction prevented the liquid concrete from adhering to the building. Under the tank is an asphalt-lined seawater return culvert within which is a drain pipe running to waste From this drain pipe there is a connexion, through a valve, to the tank floor and through an open pipe another branch leads to a covered sump in the public hall. A drain in the tank sill, controlled by a valve, can discharge water into the culvert and so back to the reservoirs. At the apex of the triangular tank there is an overflow serving all three tanks, a swim-way between the two larger tanks, and to the latter an inflow each. These structures are shown in greater detail, viewed from above, in Text-fig. 5. A portion of a cat-walk is shown, and in the wall on the nearside a safety overflow from the triangular tank is seen. Still farther forward are two inflows, one of them to the triangular tank. The polythene branch pipe, with Saunders valve, serving the inflows, leads down from the sea-water main at ceiling level. Nearby is the main compressed-air pipe, but no valves or branch connexions to this are shown. In the public hall are seen the handrail with supports inserted in the concrete sill; label frames between it and the glass; and below the sill, fluted asbestos sheeting down to floor level. 
much of it quickly disappeared down the overflows (Wilson, 1952, p. 199). In the new aquarium all the inflowing water enters at or near the bottom. The nozzles spray the water into corners of the tanks cut off by sliding sheets of black polythene perforated near their bottom edges with rows of small holes (Text-figs. 4, 5 and Pl. II, fig. I), or spray it into special channels inset in side walls, or into large-bore pipes with similar rows of holes at their lower ends. In the large tank these pipes are concealed behind the window mullions. In this way the incoming water is aerated and led directly to the bottom. The depressed area in the big tank is provided with a special inflow pipe functioning in much the same way. None of these inflows is visible from the public hall. During the long and warm summer of 1959 when aquarium temperatures were unusually high (over $18^{\circ} \mathrm{C}$ for 6 weeks) almost all the animals were in better health than had been usual with the old aquarium even for a normal summer.

Asbestos overflow pipes of 4 in. bore are cast into the concrete walls, mainly at the apices of the triangular tanks. A view looking down on one of these is seen in Text-fig. 5. Short asphalt-lined passageways lead the overflow water from three tanks to the overflow pipe, which discharges it directly into the underlying culvert. The entrance to each passage is guarded by a perforated sheet of polythene held in grooves formed in asphalt. The V-shaped notches in the lower edges of these sheets ensure that the surface-film water is drawn off; this is important, for should the surface-film be trapped a scum of dust from the air and oily matter from food, etc., will accumulate over the whole surface. Through the side walls of each triangular tank openings slightly above normal water level are fitted with perforated vulcanite sheets held in slate grooves (Text-fig. 4 and Pl. II, fig. I); these are safety outlets should the proper overflow become obstructed. On the south side there are three overflow pipes serving six tanks; four overflow pipes serve four north-side tanks, the big end tank and the two corner tanks, and all seven tanks can overflow into one another. It is thus impossible for tanks to overfill unless all overflow pipes of a series are simultaneously blocked, which is virtually impossible.

The divisible floor-tank in the north-west corner has two large-bore overflow pipes draining away surface-film water to keep it clear.

\section{Compressed air}

In the new aquarium compressed air is used for two purposes only: (I) for lifting water from lower levels to the surface, thereby assisting in maintaining water movement within the tanks; (2) for imparting a rippled surface to bring about a play of light and shade over rocks and gravel, as occurs naturally in shallower regions of the sea.

The air is bubbled up inside pipes of 3 in. bore (concealed behind two window mullions on the north side), or in tank corners behind polythene sheets 


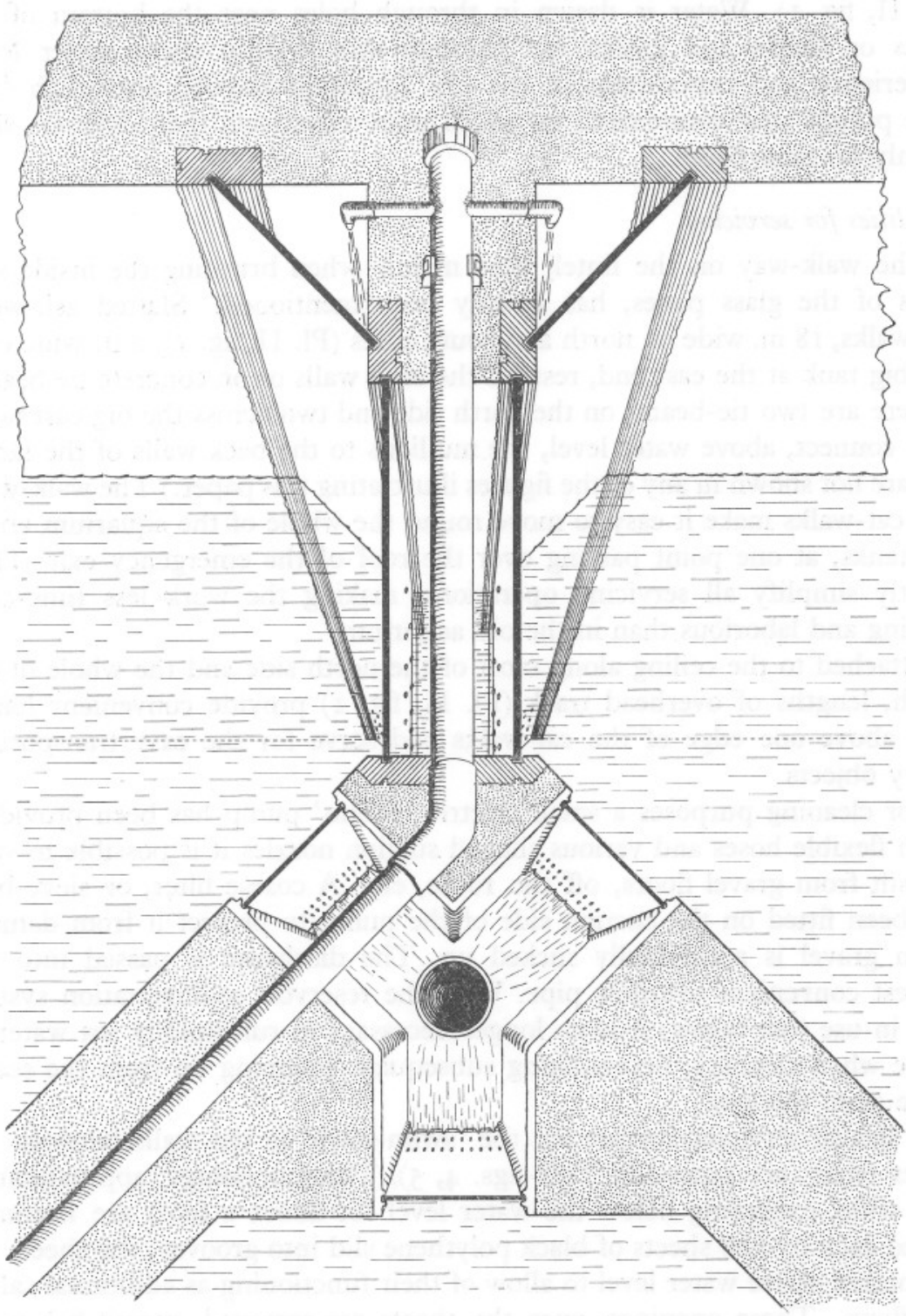

Text-fig. 5. Perspective drawing looking down on an overflow serving three tanks, a swimway between two tanks, and inflows to two tanks. The top faces of the concrete are stippled; of the slate inserts hachured; while the top edges of the sliding polythene sheets are solid black. The top edges of the asphalt lining of the overflow channels are unshaded. Water is shown by dashed lines. 
(Pl. II, fig. I). Water is drawn in through holes near the bottom of the pipes or sheets and gushes out through slits slightly above water level. Experience and experiment in the old aquarium showed that such 'airpipe pumps' use compressed air much more effectively than diffusers sited openly on tank floors.

\section{Facilities for servicing}

The walk-way on the lintel, used mainly when brushing the inside surfaces of the glass panes, has already been mentioned. Slatted ash-wood cat-walks, 18 in. wide on north and south sides (Pl. II, fig. I), 2 ft. wide over the big tank at the east end, rest on the tank walls or on concrete tie beams. (There are two tie-beams on the north side and two across the big east tank; they connect, above water level, the mullions to the back walls of the tanks, but are not shown in any of the figures illustrating this paper.) The walk-ways and cat-walks make it easy to move round the whole of the aquarium above the tanks, at one point passing over the roof of the emergency exit. They greatly simplify all servicing operations, making the work less time-consuming and laborious than in the old aquarium.

Attached to the ceiling along most of the north side and the whole of the south, lengths of overhead track (Pl. II, fig. I) provide convenient handrails above one edge of the cat-walks and serve for the easy transport of heavy objects.

For cleaning purposes a small electric 'Mono' pump has been provided. With flexible hoses and various shaped suction nozzles it is possible to suck out silt from gravel floors, off the rocks, etc. A coarse filter, or sieve-box, has been fitted on the suction side of the pump to protect it from damage when gravel is accidentally sucked up. The discharge is passed into the nearest convenient overflow pipe. With the reservoir sedimentation system now in use (see below) it is no longer necessary to run muddy sea water to waste when cleaning, necessitating subsequent pumping up from the sea to make good the loss.

A special servicing feature are the 'swim-ways' in the walls between the larger tanks (see especially Text-figs. 4, 5). These openings (approximately I ft. wide, extending below the water level for about a foot) are normally closed each by two sheets of black polythene slid into grooves; the sheets are perforated above water level to allow of their functioning as additional safety overflows. These openings, once the sheets are removed, permit fish to be swum from one tank to another as desired. Thus during a major tank-cleaning operation the fish of one tank will be netted and removed to storage tanks in the yard, choosing for netting easily caught and not readily damaged species such as dogfishes and conger eels. The swim-way adjacent having been made watertight (with a bolted-on cover and sealing compound) this tank will be emptied, cleaned and reflooded. The swim-way will then be opened and the 
fish in the next tank (species such as whiting which are easily damaged by netting) will be driven through into the cleaned tank and shut off there. Their tank in its turn will be emptied and cleaned and made ready for the reception of fish from a tank farther on. Finally, when the whole series has been emptied and cleaned one at a time, the fish will be driven back into their own tanks and the dogfishes and conger eels brought back from the yard. In this way handling of fish will be reduced to a minimum.

In the north-west service area (Text-fig. I) a number of small asbestos tanks are used to store live food (shrimps, crabs, mysids, worms, etc.) and to accommodate recently caught small animals until such time as they are placed in the exhibition tanks. This corner also houses the 'plunger-bucket' (to work 'plunger-jars' in a laboratory above) which is supplied with water from the north-side series of tanks.

\section{Lighting}

It is hardly possible to light an aquarium satisfactorily by daylight. Daylight is too variable in intensity and whatever the orientation of the tanks some will always be more brightly lit than others. When the sun shines strong reflexions of the sunny side will be seen in the darker side unless a curtain, as in the old aquarium, be hung down the middle of the public hall. Too much daylight induces rapid growth of small algae which on dying break up and produce silt; the result is dirty tanks. Back-lighting from windows behind the tanks, a standard feature of many Victorian public aquaria some of which still survive, illuminates the sides of the fish away from the viewer and leaves the backs of the tanks in semi-darkness. A few translucent objects-some sea anemones, ascidians, dogfish eggs, etc.-look well when back-lit but the majority of opaque animals do not. The tanks should be more strongly lit than the public hall, to avoid as far as possible reflexions of people in the glass and to make the tanks appear as a series of bright living pictures within their darker frames.

To exclude daylight the south-side windows have been fitted inside with asbestos sheeting. On the side facing the glass the sheeting is enamelled dark blue, purely as an architectural feature when seen from outside the building. Three windows have been left to open to obtain ventilation while admitting a minimum of daylight (Pl. II, fig. I). On the north side the windows are sufficiently screened from the sky by the roof over the new outside tanks (see below).

The public hall (Pl. I) is lit mainly by light passing through the tanks aided by a series of recessed lights in the suspended ceiling. It is dim but not completely dark, there being sufficient illumination to see any object on the floor and to allow the Guide Book to be read.

Over the tanks two lines of electric conduit tubing are fixed at main ceiling level, one between the cat-walk and the glass and the other between the cat- 
walk and the backs of the tanks (Pl. II, fig. I). At selected points screwed waterproof three-pin sockets are provided from which hang the lights, the heavier ones on chains. Over most tanks there is one main light (usually a $200 \mathrm{~W}$., occasionally $100 \mathrm{~W}$. bulb inside a watertight reflector fitting) 12 in. above water level and 12 in. from the top edge of each glass pane. The back lights are more numerous and more variable; they are mostly roo W. bulbs in watertight fittings, but fluorescent tubes, protected from damp, are used in places. The back lighting has been arranged to give the most effective illumination of the rock scenery and therefore varies from tank to tank; the front lighting is more constant as it is intended mainly to illuminate the animals. The triangular tanks have only one light, the front one, but special effects can be arranged if needed. Front and back lights are independently fused and switched.

In addition to the main lights, low-wattage bulbs in waterproof plastic bulkhead fittings fixed at a small number of places on the ceiling directly above the tanks (Pl. II, figs. I) are switched on whenever the main lights are off. These night-lights give sufficient illumination for a number of active fishes to avoid obstructions at night. They probably help the mackerel and some other pelagic fish and they definitely do help Smooth Hounds (Mustelus mustelus) and Spur Dogs (Squalus acanthias) to avoid bumping their snouts on rocks in the dark. The provision of night-lights was recommended long ago by Saville Kent as a result of his experiences in the former Manchester Aquarium (opened I874) and their benefit to these same species was noticed independently at Plymouth some years ago.

The floor-tank is lit partly from above by flood-lamps shining down through holes in the canopy over the tank, and partly from lamps behind plate-glass windows in the front wall below water level. The lights are so masked and positioned that they illuminate only the floor of the tank, and none of the surrounds above water level. No lamps or their reflections are visible from normal viewing positions.

At suitable points on the walls behind the tanks three-point 5-amp switch sockets are provided. These are intended for the electric cleaning pump but are available for special or temporary lighting if required.

\section{Rockwork}

Few fish are completely at ease in a bare-walled tank. Many invertebrates and some fishes need to be provided with rocky nooks and crannies and with a floor of natural sands or gravels. When an aquarium is intended to attract a paying public the appearance of this rockwork and the treatment of the tank walls is of paramount importance in providing an aesthetically pleasing background against which the animals are viewed. The success or otherwise of the scenic presentation cannot fail to influence receipts at the cash desk.

As the Plymouth aquarium is intended almost entirely for local marine life 
it was decided to base the scenic presentation on local rocks and of these the beautiful Devonian limestone forming the northern boundary of the Sound was considered most suitable. The rock is very hard and is often bluish white in colour, pink or streaked with pink. Water-worn rocks of various sizes could be picked up from higher tidal levels, and by careful attention to bedding planes could be built into natural-looking cliffs in the tanks. In addition to the use of real rocks rubber-latex moulds were made of small portions of waterworn cliff faces and used to produce artificial rock 'tiles'. One face of each tile exactly reproduces the shape and texture of the natural rock on which the mould was made. The other face, being flat and scored, forms a 'key' for cementing to the back walls, especially of the triangular tanks where it is necessary to keep the thickness of the added rockwork to a minimum. Joints between adjacent rock tiles are filled with cement and sand and modelled to merge the natural mouldings of the various tiles into one apparent solid rock face. A little of the rockwork in one triangular tank is seen in Pl. II, fig. I. A strong mix $(\mathrm{I}: 3)$ of sulphate-resisting cement and crushed limestone which had passed a $\frac{1}{4}$ in. sieve was used in making the tiles. Before filling the moulds with the mix the rubber was wetted with a strong solution of 'Teepol' to prevent the adhesion of air bubbles and, after filling, the moulds were vibrated to eliminate all air trapped in the mix. For fixing the tiles to the tank walls a stronger mix $(1: 2)$ of sulphate-resisting cement, fine sands and waterproofer was used. Finally, the artificial rock faces were painted to resemble natural rocks. The epoxy resin paints used are non-toxic, are very hard and should withstand repeated cleaning. The final effect is excellent, it being difficult to distinguish artificial rocks from natural and impossible once they are covered with natural growths.

Where the back wall of a tank is left bare it is painted with epoxy resin paint of a moderately dark-green shade to simulate the effect of the greenness seen on looking through many feet of sea water. Near the backs of certain tanks frosted (sand-papered) sheets of Perspex pleasantly diffuse the background to give an appearance of distance; they eliminate shadows which would otherwise show on the walls. Scenic paintings of apparently distant rocks on the walls behind such sheets increases this illusion of remote vistas. The sheets are mostly 6 in. in front of the back wall of the tank, but sometimes are farther away and fish allowed to pass behind. They are held by slotted slates hidden in the rockwork. In arranging such sheets it is essential that side and bottom edges be concealed from view, for if seen the illusion is destroyed.

The angled-out side walls of the larger tanks are painted white (Pl. II, fig. I), again with epoxy resins. This white surface is, of course, invisible to the public and it helps to reflect back into the tank some light which would otherwise be lost. To conceal the far corners of these tanks, with their inflows and swim-ways, rock cliffs are built against the side walls a little in front of them. 
Fish can pass out of sight behind these cliffs but most fishes remain in view. Only lobsters, dogfishes, conger eels and wrasses have been troublesome, often hiding in the concealed corners, and special measures are taken to deal with them. Thus if there are more lobsters in a tank than there are hidden corners some will be forced to occupy holes in full view. Fish swimming into view from behind these cliffs and disappearing again behind them seem to come and go as they would naturally do among rocks in the sea.

After the rockwork was built the bottom of every tank was covered with a layer of sulphate-resisting cement and sand, to which a suitable yellow colouring agent had been added, and rendered to a thickness of an inch. While still wet the rendering was strewn with sand or gravel, gently patted in by hand and given a rippled surface as on a sandy sea shore. Now when fish disturb the loose sand or gravel the rippling helps to retain it in position and where patches of floors are uncovered they match well the sand or gravel and do not look like bare concrete. It is important that the bottom screeding be carried out after the rockwork is in position so that rocks emerge from it as from a natural deposit.

\section{Aquarium reservoirs and water treatments}

The provision of clean well-aerated sea water of as near normal chemical and physical constitution as possible is essential to the well-being of an aquarium. Until very recently the water supplied to the tanks of the Plymouth aquarium (from reservoirs for a description of which see Wilson, I952, p. 204) has always been loaded with varying quantities of silt, although generally satisfactory in other respects. Quite early in the history of the place much effort was expended to free the water from silt, as well as to improve it in other ways. There is frequent reference to these efforts in early Reports of Council and Director's Reports published in early volumes of the Fournal. Various filters were devised which seem to have functioned for a time but which cannot have proved satisfactory for long. Conditions at one time were evidently so bad that doubts were expressed concerning the efficiency of closed sea-water circulation systems and a single use of water, at least for the laboratory, advocated (F. mar. biol. Ass. U.K., Vol. 4, pp. 77 and 4I7; Vol. 5, pp. 98-99).

The first major improvement to the condition of the circulating sea water was made when regular treatment with slaked lime (to remove carbon dioxide and restore the $\mathrm{pH}$ ) was instituted sometime after 1922 (Atkins, I93I). The silt trouble remained and occasions when it was possible to view with some clarity the backs of the largest tanks through $9 \mathrm{ft}$. of water were regarded as almost noteworthy. Most of the silt was formed in the tanks by the decay of plant growths, the breaking up of faeces, etc., and it was kept in suspension by the stirring activities of the animals, especially bottom fishes. All but the heavier components were carried away in the overflow water and discharged at the surface into one of the two underground reservoirs. From this reservoir 
water was being drawn off to the pumps at a point about $3 \mathrm{ft}$. from the bottom, and with it any silt still in suspension. There was thus a steady buildup of suspended particles and the longer the water had been circulating the cloudier it was. The cloudiness of the water in the reservoirs was such that the bottom at a depth of $\mathrm{II} \mathrm{ft}$. was rarely visible; often it was not possible to see anything at even half that depth. Allowing each reservoir to rest and sediment alternate weeks was only partially successful in clearing the water (see below). The system has been described and criticized in Wilson, 1952, pp. 204 and 209. A method of sedimenting off the silt there suggested has now in modified form been adopted with excellent results.



Text-fig. 6. Diagram of the sea-water reservoirs (not to scale and with roof omitted) to show method of circulation now in use. The direction of water flow is indicated by the arrows.

The method now in use involved no more than minor modifications to the existing reservoirs. These are shown diagrammatically in Text-fig. 6. Water returns from the aquarium along a $\mathrm{I} \mathrm{ft}$. diameter pipe in the wall dividing east and west reservoirs. At its northern end there is a T-junction where sluices divert the water to one or other of the reservoirs as required; in the old days it would be the reservoir from which water was being pumped, there being then no communication between reservoirs.

During the construction of new underground reservoirs for the new laboratory circulation (see below) the east reservoir had to remain empty for 6 months and only the west reservoir was in use. During this period the water became so dirty that in the aquarium anything farther from the glass than about $2 \mathrm{ft}$. disappeared from view in a fog of suspended silt. This gives some measure of the partial success of the old method of alternating reservoirs. While the 
east reservoir was empty a wall was built across its north-west corner and from the bottom of this wall a culvert of brick sides with removable slate top was constructed across the reservoir floor to near its south-east corner. A 6 in. drain pipe was inserted through the dividing wall at the north end, passing under the larger return pipe from the aquarium. With both reservoirs flooded the return water now discharges into the corner cut off by the wall and passes along the culvert to emerge near the south-east corner at the bottom as shown by the arrows in Text-fig. 6 . This brings about a continuous overflow of surface water from the east to the west reservoir from whence it is drawn off to the pump through the old suction pipe in the south wall. However dirty the incoming water (as with silt-laden water from the discharge of the cleaning pump), that which rises up to overflow into the west is always crystal clear. The silt settles out over the floor of the east reservoir where mixed with lime (lime is now put into the east reservoir only) it shows no tendency to blacken or smell and could be left there for years. The water in both reservoirs is so clear that the smallest details are visible on the bottoms of both, and visibility in the aquarium tanks is almost always perfect, showing only slight cloudiness on feeding days (due mainly to defaecation) or when fish stir up the bottom gravel. It has been mentioned that after 6 months continuous use of the west reservoir the water in the aquarium was exceptionally dirty, but only 4 days after putting the new system into operation visibility was better than anyone could remember.

Apart from the deposition of silt the new method gives better aeration. Whereas under the old system the returning water was cascaded once into a reservoir to sink down to the pump intake, this water is now cascaded twice. Moreover, it is surface water in contact with air in a well-ventilated space which is cascaded into the west reservoir. Tests of water from the middle depths of the latter have shown close approximations to $100 \%$ oxygen saturation.

Means are provided whereby it is easy to revert to the old system of using one reservoir only. This is occasionally necessary for a day or two while one or other of the reservoirs is emptied and cleaned. The method of refilling from the sea was described in Wilson, I952, p. 205. Sometimes the west reservoir is only partially emptied and the system freshened with new water from the sea pumped into the east reservoir.

The total quantity of sea water held by the reservoirs is about I I0,000 gallons when both are completely full, while the total quantity of water in aquarium and service tanks is roughly 17,000 gallons. At the present time the water is circulated at a rate of about 3000 gallons an hour (for description of the pumps see Wilson, I952, p. 204). This rate is barely adequate, especially in hot weather, and it is desirable to increase the rate to 4500 gallons per hour or even more. 


\section{NEW CIRCULATION}

An ever-increasing need for more live-specimen storage accommodation, and for research purposes cleaner water less heavily stocked with animal life, led to a decision to build an entirely new circulation system independent of the main aquarium and its ancillaries. Thus, commencing in October 1955 new reservoirs were excavated in the yard between south and north buildings and a new series of outside tanks were built to replace the smaller series illustrated and described in Wilson, 1952, pp. 202-3. The new system was brought into operation for the first time early in September 1957. The contractors for these new reservoirs and new outside tanks were Messrs A. N. Coles (Contractors) Ltd., Plymouth.

\section{New reservoirs}

A large hole was excavated in hard limestone to the east of the aquarium reservoirs. In this hole new reservoirs were constructed in concrete (using sulphate-resisting cement) and lined with a rendering of waterproof concrete coated with bituminous paint. They were roofed over at road level with concrete and tarmacadam. The roofing is designed to take a load of 12 tons. At convenient places manholes give access to the reservoirs below. Each reservoir holds about 16,000 gallons of sea water when full and there is a wellventilated air-space of about $2 \mathrm{ft}$. between the underside of the roof and the water surface. The dividing wall between the reservoirs has three wide openings $8 \mathrm{ft}$. 9 in. above reservoir floor level. Water returning from the tanks cascades into a partitioned-off space in the south-east corner of the east reservoir and is there forced to descend to the bottom where silt is deposited. As this east reservoir fills up it overflows the dividing wall through the openings mentioned and cascades into the west reservoir. The depth of the water as it passes over the flat top of the $\mathrm{I} 2$ in.-wide wall is very shallow; thus the whole volume of the water as it circulates is at these places brought into close contact with air. From a position $4 \mathrm{ft}$. above floor level at the west end of the west reservoir the water is sucked away through a black polythene pipe of 3 in. bore to the pumps. The east reservoir is limed weekly through an inspection cover. Provision is made for working from either reservoir only while the other is emptied and cleaned. Each reservoir is provided with a drain hole and plug at its south-west corner and the floor slopes downwards slightly to the drain hole. The 4 in. drain pipe passes under the floor of the new west reservoir and passes through the south end of the old east reservoir of the aquarium circulation to join the main drain. The depth of water in the new reservoirs varies between 8 and $9 \mathrm{ft}$. when full. The reservoirs are filled through a 4 -in. bore iron pipe and through valves connecting with the pumping system used for filling the aquarium reservoirs (Wilson, I952, p. 205). Compressed air can be supplied to the west reservoir should it ever be needed. 
Electric lights in watertight bulkhead fittings are fixed to the roof of each reservoir and are switched from the pump-room in the basement of the south building.

\section{New outside tanks}

Under a new roof a new series of outside tanks was used for the first time in September 1957. They comprise (Text-fig. I and Pl. II, fig. 2) three blocks of concrete tanks (painted internally with bituminous paint) and nine large (I00 gallon) and four small ( 20 gallon) asbestos tanks on raised plinths (Text-fig. I). A double tier of slate shelving, built partly against the main building and partly against a wall at right angles to it, forms a circulation unit for bowls and jars. Four of the concrete tanks are divisible by asbestos sheets sliding in grooves; a fifth is bowl-shaped to accommodate squid and cuttlefishes. The water depth of the smaller concrete tanks is roughly 19 in., while the water depth of the large central tank can be varied at will at $23,3 \mathrm{I}$ and 36 in. by placing rubber bungs in the lower overflow holes. All overflow pipes pass down inside the thickness of the tank walls and are fitted with plastic bowl-shaped sieves ('salad-shakers' from a local store) to prevent the ingress of large objects. These overflows discharge into a culvert below ground level which returns overflow water to the reservoirs. The culvert and the lower ends of all overflow pipes are readily accessible through a series of manholes. Inflow pipes are also within the thickness of the walls and discharge into the tanks close to the bottom.

The asbestos tanks are fitted with black polythene piping for inflows and overflows. They can easily be removed and other tanks of different sizes put in their place.

At the time of writing, all tanks east of the circulation benches are supplied from the new reservoirs, while the benches themselves and the tanks west of them are on the aquarium circulation. It is possible for the largest concrete tank and the three asbestos tanks near its western end to be supplied with water from the aquarium circulation should this ever be necessary.

Electric lights for viewing the outside tanks at night are provided under the roofing. It is intended at some future date to fit shutters which in summer will slide up out of the way under the roof, but which in winter can be pulled down to enclose the tank space and protect the system from frost.

\section{New pumps}

The new circulation is maintained by paired 'Mono' pumps with stainlesssteel impellers inside rubber stators. Driven by 3 h.p. three-phase motors each unit delivers about 3600 gallons an hour. One pump is run for several weeks while the other is serviced and rests as a stand-by. Adjustments to the gearing of the $\mathrm{V}$-belting will enable these pumps to give a greater output should this in future be needed. At present the output is more than ample as it 
is serving only the outside tanks and those on the first floor of the main laboratory (as described in Wilson, 1952, p. 203, ${ }^{1}$ and illustrated in Russell, I948, pl. XIX).

\section{Circulation efficiency}

The total capacity of the outside tanks and those on the first floor is about 2600 gallons; this being less than a twelfth of the reservoir capacity, a much smaller proportion of tank volume to reservoir volume than in the aquarium circulation. The relative rate of flow of the water is also much greater. Even when eventually more experimental tanks in the new block of buildings now being planned are added the new circulation will contain less animal life per unit volume than the aquarium circulation, and be relatively more efficient in every way except temperature stability. There is no regular means of heating or cooling either circulation, and while temperature changes are slow the new circulation is more affected by the weather than is the old. This is because the total volume of water is less than in the aquarium circulation and a greater proportion of it is exposed to air temperature and wind in the yard. When shutters are fitted to close in the outside tanks in winter it will be possible to reduce the rate of loss of heat, though it is doubtful if shutters will help to check rise of water temperature during hot days in summer.

My thanks are due to Mr G. A. W. Battin for making the drawings for this paper and Mr A. C. G. Best for help with the photography.

\section{REFERENCES}

Allen, E. J. \& Harvey, H. W., I928. The Laboratory of the Marine Biological Association at Plymouth. F. mar. biol. Ass. U.K., Vol. 15, 735-5I.

Atkins, W. R. G., I93I. Note on the condition of the water in a marine aquarium. 7. mar. biol. Ass. U.K., Vol. 17, pp. 479-8I.

GARNAUD, J., I952. Structure nouvelle de l'aquarium moderne et autres améliorations techniques. Bull. Inst. océanogr. Monaco, No. I,or I, pp. I-IO.

Russell, F. S., I948. The Plymouth Laboratory of the Marine Biological Association of the United Kingdom. F. mar. biol. Ass. U.K., Vol. 27, pp. 761-74.

WILsON, D. P., I952. The aquarium and sea-water circulation system at the Plymouth Laboratory. F. mar. biol. Ass. U.K., Vol. 31, pp. 193-212.

— I953. Notes from the Plymouth aquarium. II. F. mar. biol. Ass. U.K., Vol. 32, pp. 199-208.

1 Except that the overflow water from these main laboratory tanks no longer runs into exhibition tanks in the aquarium below but is conducted by new piping to the return culvert to the new reservoirs. 


\section{EXPLANATION OF PLATES}

Plate I

General view of the new aquarium from the public entrance lobby. Note the handrail, label frames, ceiling with inset lights, etc. (A photograph of the old aquarium from almost the same viewpoint is reproduced in Russell, I948, pl. XXIII, fig. I.)

\section{Plate II}

Fig. I. View along the tops of the tanks of the south side from the west end. Note especially the shapes of the tanks, the lintel walk-way and cat-walks, the overhead conveyor track, details of inflows and overflows so far as visible, sea-water and compressed-air pipes (one of the latter on tank-back near right foreground), light fittings, etc. Compare especially with Textfigs. 4 and 5 .

Fig. 2. View of new outside circulation tanks and circulation bench from the western end. Note in right foreground a pair of concrete tanks painted internally with black bitumen. Further on is the double-tiered circulation bench for bowls, and, in front, four small asbestos tanks on a low circulation table. Behind the circulation bench the outer of three large asbestos tanks, on a raised plinth, is seen. Farther on still is the large and deep concrete tank, then a pair of shallower concrete tanks similar to those in the foreground. Beyond these part of a row of three large asbestos tanks is just visible. (For photographs of the old outside circulation which these tanks replace see Russell, 1948, pl. XXII, fig. 2, and Wilson, I952, text-fig. 4). 


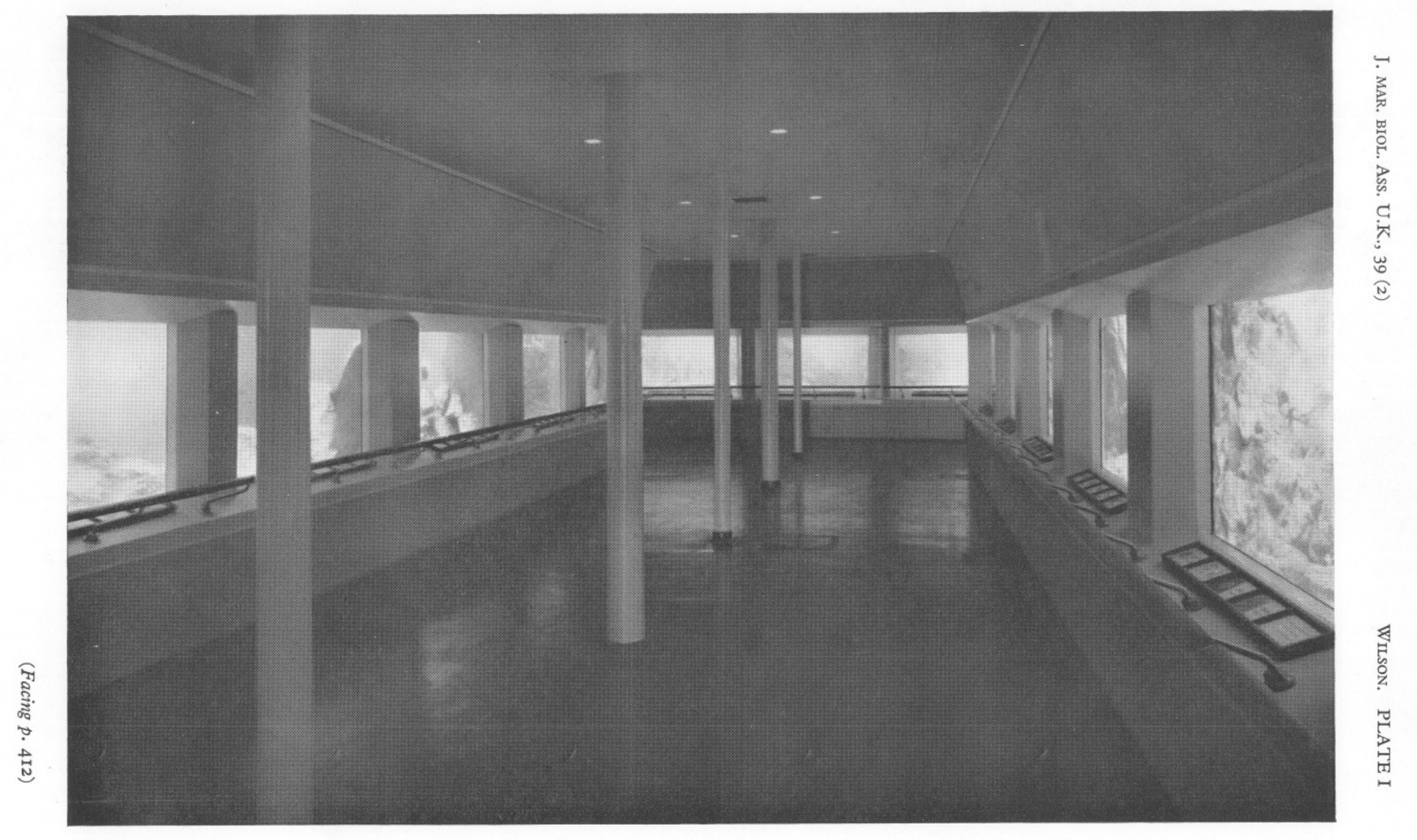




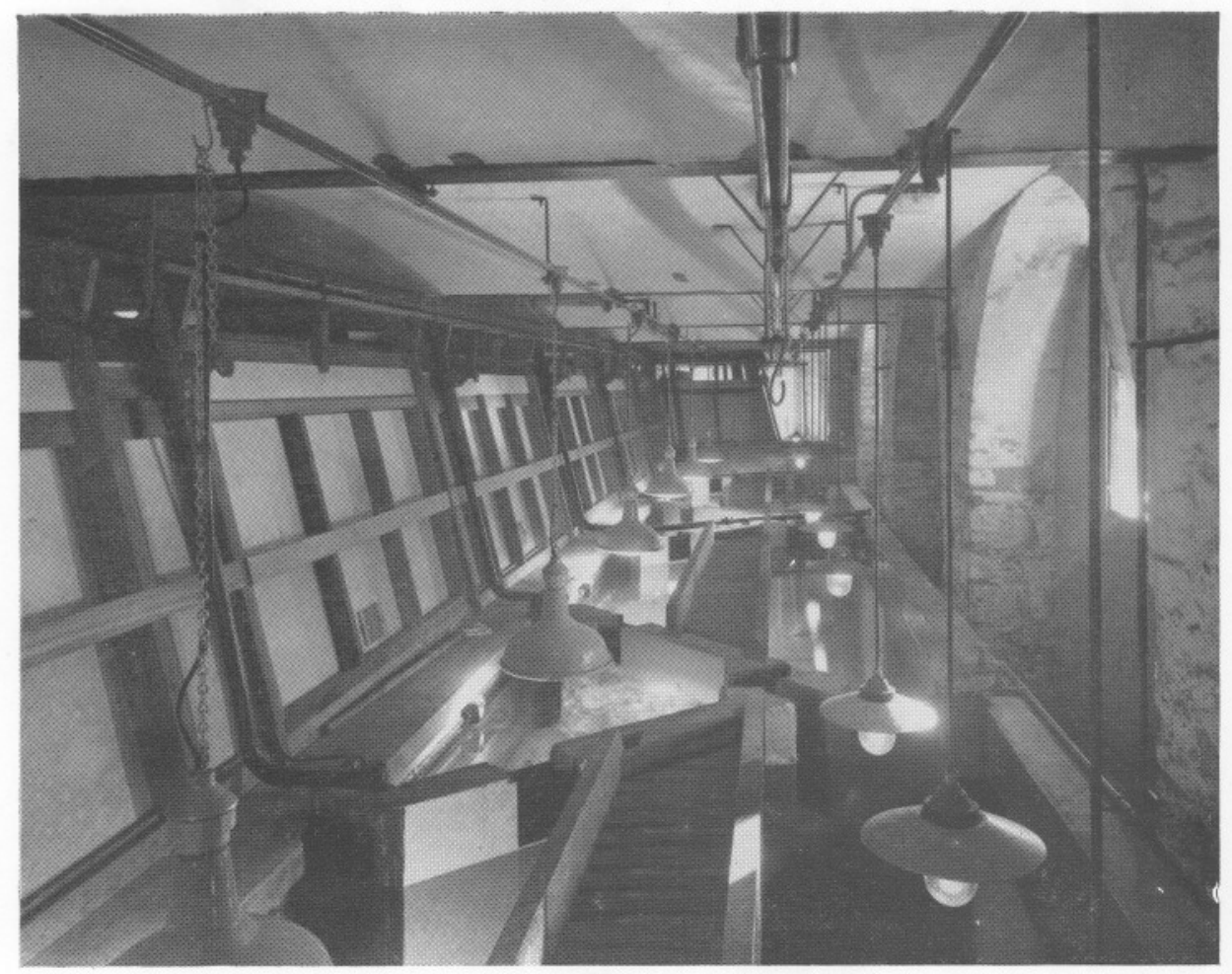

Fig. I .



Fig. 2. 


\section{ABSTRACTS OF MEMOIRS}

\section{RECORDING WORK DONE AT THE PLYMOUTH LABORATORY}

Boney, A. D., CoRner, E. D. S. \& SPARrow, B. W. P., 1959. The effects of various poisons on the growth and viability of sporelings of the red alga Plumaria elegans (Bonnem.) Schm. Biochem. Pharmacol., Vol. 2, pp. 37-49.

Mercury, silver, copper and arsenic are more toxic than the non-metallic inhibitors hydrocyanic, hydrazoic, iodoacetic, fluoroacetic and malonic acids and $2: 4$-dinitrophenol to sporelings of Plumaria elegans in sea water at $\mathrm{pH} 8 \cdot \mathrm{I}$. Mercury and silver are more toxic than copper and arsenic, and the toxicities of mercury and arsenic are greatly increased when these poisons are used as lipophilic organic compounds (e.g. phenylmercuric chloride and phenarsazine chloride). All heavy metals are less toxic when used in the presence of reduced glutathione.

The toxicities of an homologous series of primary $n$-alkyl-mercuric chlorides increase to a maximum with that of $n-\mathrm{C}_{5} \mathrm{H}_{11} \mathrm{HgCl}$. Lipoid solubilities based on methyl-oleate : sea-water partition coefficients correlate with appropriate toxicity data for the first three members of the series, but those of $n-\mathrm{C}_{4} \mathrm{H}_{9} \mathrm{HgCl}$ and $n-\mathrm{C}_{5} \mathrm{H}_{11} \mathrm{HgCl}$ increase without any corresponding rise in toxicity. The 'cut-off' in relative toxicities within the homologous series is not found in complementary experiments with crustaceans.

Mercuric iodide is much more toxic than $\mathrm{HgCl}_{2}$ to Plumaria and crustaceans, but whereas various organic compounds of mercury become markedly more toxic to crustaceans when used in the presence of excess KI, their toxicities to Plumaria are not increased.

E.D.S.C,

BuRSA, A. S., 1959. The genus Prorocentrum Ehrenberg. Morphodynamics, Protoplasmatic Structures and Taxonomy. Canad. F. Bot., Vol. 37, pp. I-3I.

The morphodynamics of Prorocentrum have been studied comparatively in cultures and in plankton. Plankton populations show little morphological variation. In cultures a variety of forms, often similar to other species of Prorocentrum which have been described from distant seas, are found. Morphological variation in Prorocentrum species depends upon various life phases, individual features of the clones, and various types of cysts. Formation of the morphological aberrants is also affected by ageing of cultures. All protoplasmatic structures, including the cell membrane, possess their own particular features, changing in course of life cycle. Since both physiological and morphodynamic metabolisms are inseparable in their activities, it is useful to complete taxonomic diagnoses with physiological observations. Five new species are described: Prorocentrum cordiformis, $P$. pomoideum, $P$. pyrenoideum, $P$. redfieldi and $P$. levantinoides. Morphodynamics in $P$. micans and $P$. scutellum was also studied. Most observations were made in vivo. Specific morphological differences in form and structure of protoplasmatic organelles were demonstrated in each species concerned. An attempt was made also to base taxonomic diagnoses upon the apical tooth, trichocysts, and membrane structure. 
CARLISLE, David B., I959. On the neurosecretory system of the brain and associated structures in Sipunculus nudus, with a note on the cuticle. Gunma F. med. Sci., Maebashi, Vol. 8, pp. 183-94.

In Sipunculus nudus a pair of dorsally situated postero-lateral groups of neurosecretory cells in the brain contain each about thirty large cells. The axons run forward to the unpaired sensory organ, a cavity in the brain connected to the mouth region by a ciliated canal. Here the axons make abrupt loops among the sensory cells of this organ and then run into the finger organs, where they terminate in typical neurohaemal endings, vertical to the blood space surrounding the organs. These club-shaped endings are filled with a secretion which has staining properties different from those of the material found more proximally in the axons and cells. The likeness of this system to the hypothalamo-hypophysial system of vertebrates and to the major endocrine systems of crustaceans and insects is emphasized.

The cuticle consists of protein with no trace of chitin or mucopolysaccharides.

D.B.C.

Carlisle, D. B. \& Ellis, Peggy E. I959. La persistance des glandes ventrales céphaliques chez les Criquets solitaires. C.R. Acad. Sci., Paris, T. 249, pp. 1059-60.

The ventral glands of locusts, which are homologous to the prothoracic glands of Lepidoptera and probably to the Y-organs of crustacea, normally disappear in the adult insect. In locusts in the solitary phase, however, they may persist in a functional condition.

D.B.C.

COOPER, L. H. N., 1957. Some chemical and physical factors controlling the biological productivity of temperate and tropical oceanic waters. Proc. 8 th Pac. Sci. Cong. 1953, Vol. III A (received by the author 1959).

Differences in conditions of productivity in tropical and temperate latitudes were discussed. A pattern for observation and experiment in tropical seas was proposed. Much of the material in the paper has now only historic interest.

L.H.N.C.

CoRner, E. D. S., 1959. The poisoning of Maia squinado (Herbst) by certain compounds of mercury. Biochem. Pharmacol., Vol. 2, pp. I2I-32

When Maia is immersed in sea water containing added $\mathrm{HgCl}_{2}$ the concentration of the poison in the blood eventually rises above that in the external medium; the concentration in the antennary glands above that in the blood; and the animals excrete small but increasing amounts of mercury in the urine. Most of the poison present in the blood is attached to protein and the concentration of mercury in the blood remains constant for several weeks after poisoned animals are returned to the sea. Mercury also concentrates in various other body tissues, and very large amounts are found on the gills. Similar results are obtained when the poison is administered to the animals by injection. When, however, the poison used is $n-\mathrm{C}_{5} \mathrm{H}_{11} \mathrm{HgCl}$, although mercury again concentrates at the gills and in various internal organs, the amount detected in the blood is very small and none is found in the urine.

When the animals are immersed for progressively longer times in sea water containing added $\mathrm{HgCl}_{2}$, or are injected with increasing amounts of the poison, the total quantity of amino- $\mathrm{N}$ in the urine increases, although that in the blood remains constant. The urine : blood ratio of amino- $\mathrm{N}$ also rises when the animals are poisoned with $n-\mathrm{C}_{5} \mathrm{H}_{11} \mathrm{HgCl}$ 
although, in this case, the level of amino $\mathrm{N}$ in the blood rises as well as that in the urine. Animals poisoned with $\mathrm{HgCl}_{2}$ and then returned to the sea show an abnormally high urine: blood ratio of amino-N several weeks later. By contrast, poisoning with $\mathrm{HgCl}_{2}$ has no effect on the urine: blood ratio of total sulphate.

E.D.S.C.

LOWENSTEIN, O. \& WERSÄLL, J., 1959. A functional interpretation of the electronmicroscopic structure of the sensory hairs in the cristae of the elasmobranch Raja clavata in terms of directional sensitivity. Nature, Lond., Vol. I84, pp. 1807-8.

An electronmicroscopic study of the sensory epithelia in the ampullae of the semicircular canals of the labyrinth of Raja clavata showed that the hair processes of the sensory cells are compound structures consisting of a number of protoplasmatic filaments, one of which has the typical electron-microscopic structure of the kinocilium, namely nine peripheral plus two central longitudinal fibrillae. This kinocilium is always found on one and the same side of the hair process in a given sensory epithelium and is placed on that side of the sensory hair process which faces in the direction in which the hair process is deflected on excitatory cupula displacement. It appears that this arrangement may be of fundamental functional significance.

O.L.

PotTs, W. T. W., I959. The sodium fluxes in the muscle fibres of a marine and a freshwater lamellibranch. 7. exp. Biol., Vol. 26, pp. 676-89.

The efflux of ${ }^{24} \mathrm{Na}$ from the isolated ventricles of Mytilus and Anodonta has been measured at $15^{\circ} \mathrm{C}$ and at $5^{\circ} \mathrm{C}$. The efflux of sodium in each case is divisible into an extracellular and an intracellular portion except at $15^{\circ} \mathrm{C}$ in Anodonta where the two portions are not clearly distinguishable. The mean rate constant for the efflux of sodium from Mytilus ventricle is $2.44 \mathrm{~h}^{-1}$ at $5^{\circ} \mathrm{C}$ and $5.6 \mathrm{~h}^{-1}$ at $15^{\circ} \mathrm{C}$. The mean rate constant for Anodonta ventricle at $5^{\circ} \mathrm{C}$ is $4.6 \mathrm{~h}^{-1}$. The efflux of sodium from the muscle fibres of Mytilus ventricle averages $12 \times \mathrm{IO}^{-6} \mathrm{~mm} / \mathrm{cm}^{2} / \mathrm{sec}$ at $5^{\circ} \mathrm{C}$ and $27 \times$ ${ }^{1} 0^{-6} \mathrm{~mm} / \mathrm{cm}^{2} / \mathrm{sec}$ at $15^{\circ} \mathrm{C}$. For Anodonta at $5^{\circ} \mathrm{C}$ it averages $3 . \mathrm{I} \times 1 \mathrm{IO}^{-6} \mathrm{~mm} / \mathrm{cm}^{2} / \mathrm{sec}$. If the efflux is maintained entirely by an active process then the energy required for the extrusion is $0.26 \mathrm{cal} / \mathrm{g} / \mathrm{h}$ at $5^{\circ} \mathrm{C}$ and $0.63 \mathrm{cal} / \mathrm{g} / \mathrm{h}$ at $15^{\circ} \mathrm{C}$ for Mytilus muscle and $0.046 \mathrm{cal} / \mathrm{g} / \mathrm{h}$ at $5^{\circ} \mathrm{C}$ by Anodonta.

W.T.W.P.

WICKSTEAD, J., I960. A new record of Mytilicola intestinalis Steuer, a parasitic copepod of mussels. Nature, Lond., Vol. 185, p. 258.

Two mature female Mytilicola intestinalis Steuer, 7.0 and $8.5 \mathrm{~mm}$ long, were recorded from a locality much removed from the limits of their accepted distribution. They were taken free in the plankton in the northern Malacca Strait area, $7^{\circ} 12^{\prime} \mathrm{N} ., 97^{\circ} 12^{\prime} \mathrm{E}$. After various considerations, no satisfactory explanation could be given for their capture at such a place in such a manner.

J.W.

Wickstead, J. H. \& Bone, Q., 1959. Ecology of acraniate larvae. Nature, Lond., Vol. I84, pp. 1849-5I.

Several species of acraniate larvae were obtained during a survey of the Indo-Malayan plankton made by the Singapore Regional Fisheries Research Station. Larvae of Branchiostoma belcheri Gray were found at a permanent station in the Singapore Strait from mid-October to January. They showed diurnal vertical migratory movements, remaining on the sea-bottom during the day, and rising to the surface at dusk. 
Examination of the gut-contents showed that feeding probably only takes place at the bottom. It is suggested that light intensity is the actuating stimulus for the migration (salinity and temperature variations being insignificant), and that it serves both to distribute the species and to enable the larvae to avoid the attacks of nocturnal bottomfeeding predators.

Larvae of Branchiostoma malayana Webb, and larvae of the 'amphioxides' type (but belonging to the Branchiostomidae) were obtained at another station, on the surface, at night. This station was over deep water, and examination of the gut contents showed that the larvae fed in mid-water, hence these species are probably truly pelagic, and never live near the bottom. At a third station, 'amphioxides' larvae of Asymmetron lucayanum Andrews were collected, which confirms the identification of Amphioxides pelagicus Gunther as the larva of Asymmetron lucayanum.

Q.B.

\title{
BOOK REVIEW
}

\section{Die Westküste Südamerikas im Bereich Des Peru-Stroms}

\author{
BY E. SCHWEIGGER
}

Heidelberg-München: Keysersche Verlagsbuchhandlung GmbH, 1959.

This comprehensive work has been written by a German who has spent thirty years studying the Peru current and its manifold influence on the neighbouring land, sea and air. Its greatest value may be as a critical digest of an enormous literature about the west coast, published in periodicals with limited circulation and mostly in Spanish. The task the author set himself was great and many chapters, naturally, do not cut deep. The author's personal interest has been in oceanography, entirely from a descriptive angle. The methods of dynamic oceanography have not been used. 'El Nino', the perturbation of the Peru current which brings death to myriads of fish and $s \geq a$ birds, is examined at length. It seems that much confusion surrounds the term and anyone wishing to use it would be wise to consult this book to find out what it means. The style is friendly and discursive. Anyone in search of a worth-while problem for study may find one on every page. 
of limited growth and these form the cortical investment to the axes of unlimited growth. In Ceramium, the axes each contain a single filament of unlimited growth, that is, they are uniaxial in construction.

\section{Apical segmentation}

The basic pattern of segmentation was first outlined by Cramer (I857). Since that date there have been numerous descriptions of apical structure and segmentation.

Each segment formed by the transverse division of the principal apical cell of an axis of unlimited growth divides further to produce from four to nine pericentral cells. The mother-cells remaining after the formation of pericentral cells do not divide again but increase in size to form the axial cells (Fig. I).

The pericentral cells are formed in a definite sequence, with a fixed orientation. The first pericentral cell formed is cut off on the outer face of each segment; the 'outer face' being determined by the previous pseudodichotomy (Fig. 2F). The remaining pericentral cells are cut off successively in pairs to form a ring of cells at the apical pole of each segment (Figs. I, $2 \mathrm{~A}-\mathrm{E}$ ). This orientation of the pericentral cells is of very great importance in that it is associated with the orientation of many other structures, such as spines, tetrasporangia, etc.

\section{The axial cells}

The axial cells are formed from the mother-cells remaining after the formation of the pericentral cells. The enlargement of the axial cells is of considerable significance in that it has a profound effect upon the longitudinal growth of the axes. A comparison of the length and volume of newly formed and mature axial cells in various species of Ceramium (Table I) gives a good indication of the degree of enlargement. The enlargement of the axial cells is not

TABLE 1

\begin{tabular}{|c|c|c|c|c|}
\hline & $\begin{array}{c}\text { Size when } \\
\text { formed } \\
(\mu)\end{array}$ & $\begin{array}{c}\text { Size when } \\
\text { mature } \\
(\mu)\end{array}$ & $\begin{array}{l}\text { Increase } \\
\text { in } \\
\text { length }\end{array}$ & $\begin{array}{l}\text { Increase } \\
\text { in } \\
\text { volume }\end{array}$ \\
\hline$r$ & $4 \times 16 \times 16$ & $380 \times 316 \times 300$ & $95 \times$ & $35,000 \times$ \\
\hline$u m$ & $4 \times 20 \times 20$ & $420 \times 240 \times 220$ & $105 x$ & $14,000 \times$ \\
\hline orthia & $4 \times 12 \times 12$ & $220 \times 70 \times 80$ & $55 \times$ & $2,000 \times$ \\
\hline
\end{tabular}

Note. The dimensions, length, depth and breadth, are mean values based on measurements of 400 cells.

related directly to the age of the cell, but shows considerable variation in different parts of the plant. This phenomenon is discussed in greater detail later, with particular reference to its taxonomic implications.

The increase in size of the axial cell is associated with the development of a large vacuole. In maturing axial cells there is a peripheral layer of 
A
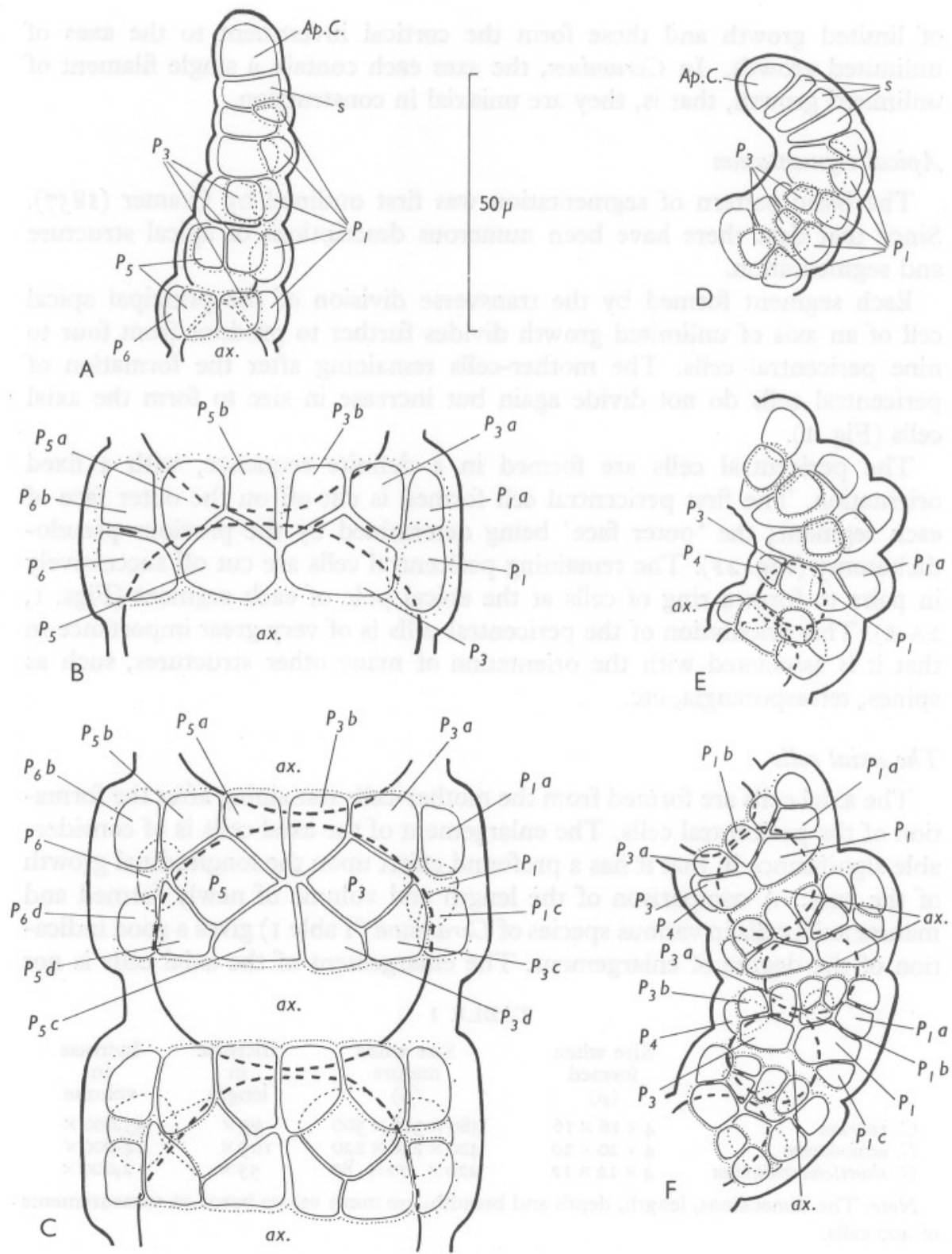

Fig. I. Apical segmentation and the development of the cortical band in the genus Ceramium. The basic pattern of segmentation in straight $(A-C)$ and curved $(D-F)$ apices is fundamentally identical, although there are obvious differences associated with the degree of curvature. Ap.C., Apical cell of an axis; s., segment produced by the transverse division of the apical cell of an axis; ax., axial cell; $P_{1}, P_{2}$, etc., pericentral cells, numbered in order of formation; $P_{1} a, P_{1} b$, acropetally directed apical cells of lateral branches of limited growth, produced from $P_{1} ; P_{1} c, P_{1} d$, basipetally directed apical cells of lateral branches of limited growth, produced from $P_{1}$. 
cytoplasm lining the wall of the cell and a central strand connecting the pitconnexions in the apical and basal walls. Elongate convolute chromatophores are distributed in the peripheral layer of cytoplasm. In those species where the cortex forms a complete investment to the axial cells, the chromatophores, even in the young cells, are only slightly pigmented. As the cells age, the
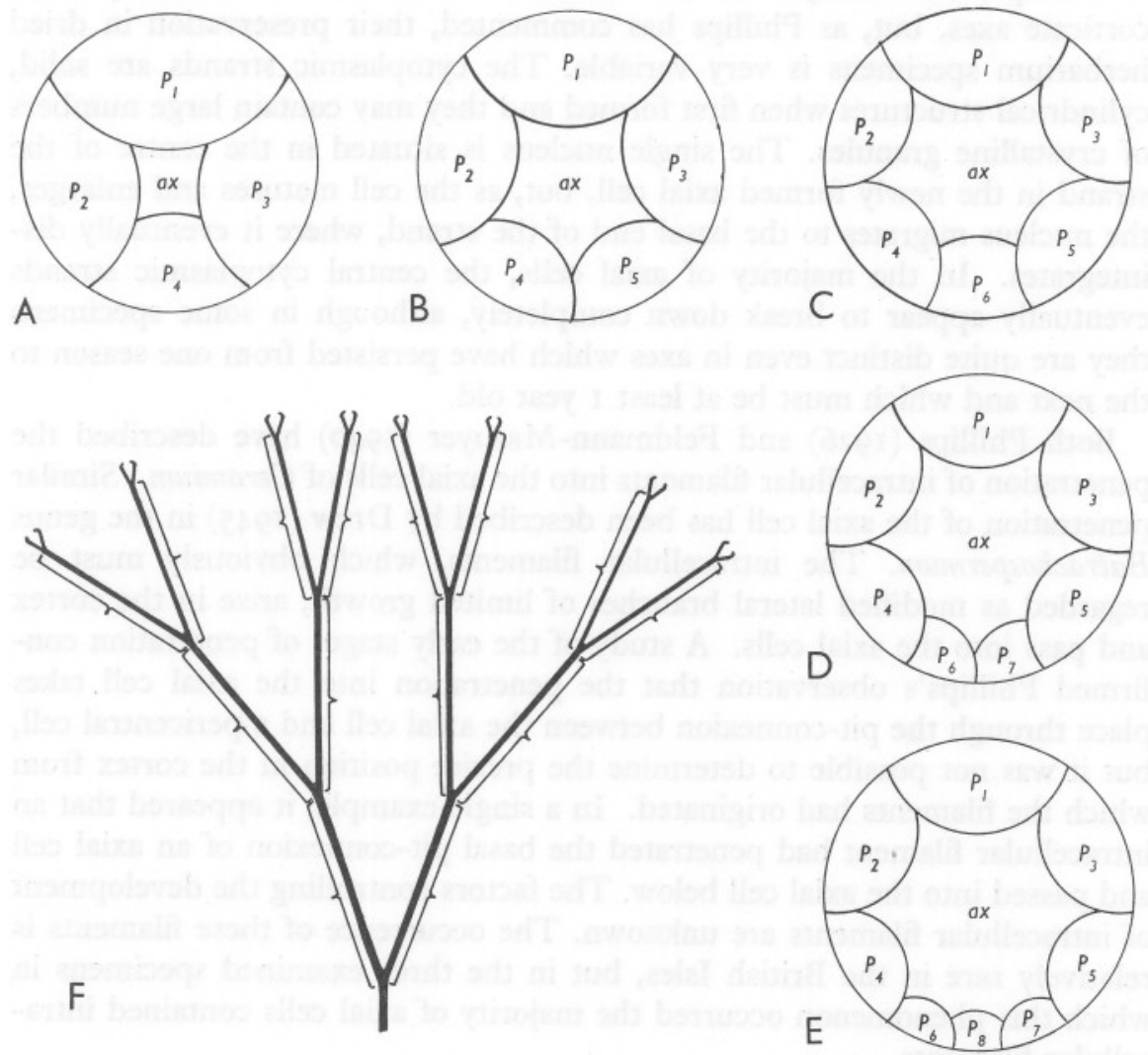

Fig. 2. A-E, Sequence of divisions in segments from which $4,5,6,7$ and 8 pericentral cells are formed; $\mathrm{F}$, outwardly directed orientation of the first pericentral cells, in relation to the pseudo-dichotomy of the axes; the positions of the first pericentral cells in each 'sector' are indicated by brackets. ax., Axial cell; $P_{1}, P_{2}, P_{3}$, etc., pericentral cells, numbered in order of formation.

pigmentation disappears completely. The chromatophores are more conspicuous in those species where the axial cell is exposed because of the incomplete cortical investment, but even so degeneration occurs with age.

The presence of a central strand of cytoplasmic material in the axial cells of Ceramium has been discussed or figured by various authors (Moore, I885; Petersen, I908; Schiller, I913; Phillips, I926; Dammann, I930, 1932; Celan, 
I939 $a, b$; Feldmann-Mazoyer, I940; Feldmann \& Feldmann, I946; Funk, I955). Phillips (I926, p. 277) has rightly commented that Moore (I886) mis-interpreted the observations of Hick (1884) on C. acanthonotum ( $=C$. shuttleworthianum). Hick's observations, which are somewhat obscure, do not refer to the central cytoplasmic strand. These strands, the 'trabeculae' of Phillips, are readily discernible in fresh material, even in completelycorticate axes, but, as Phillips has commented, their preservation in dried herbarium specimens is very variable. The cytoplasmic strands are solid, cylindrical structures when first formed and they may contain large numbers of crystalline granules. The single nucleus is situated in the centre of the strand in the newly formed axial cell, but, as the cell matures and enlarges, the nucleus migrates to the basal end of the strand, where it eventually disintegrates. In the majority of axial cells, the central cytoplasmic strands eventually appear to break down completely, although in some specimens they are quite distinct even in axes which have persisted from one season to the next and which must be at least I year old.

Both Phillips (1926) and Feldmann-Mazoyer (I940) have described the penetration of intracellular filaments into the axial cells of Ceramium. Similar penetration of the axial cell has been described by Drew (1945) in the genus Batrachospermum. The intracellular filaments, which obviously must be regarded as modified lateral branches of limited growth, arise in the cortex and pass into the axial cells. A study of the early stages of penetration confirmed Phillips's observation that the penetration into the axial cell takes place through the pit-connexion between the axial cell and a pericentral cell, but it was not possible to determine the precise position in the cortex from which the filaments had originated. In a single example, it appeared that an intracellular filament had penetrated the basal pit-connexion of an axial cell and passed into the axial cell below. The factors controlling the development of intracellular filaments are unknown. The occurrence of these filaments is relatively rare in the British Isles, but in the three examined specimens in which this phenomenon occurred the majority of axial cells contained intracellular filaments.

\section{Formation of the lateral branches of limited growth}

Each of the pericentral cells gives rise to four apical cells, two of which are directed acropetally and two basipetally (Fig. I). One or more further apical cells may be formed in those species where the cortical band is well developed. The apical cells thus formed segment to produce the much-branched lateral branches of limited growth.

The lateral branches of limited growth derived from a single segment of the principal apical cell of an axis aggregate to form an encircling band of cortex, which is adpressed to the axial cell from which it has arisen. Each cortical band envelops the lower part of the axial cell above, in addition to 

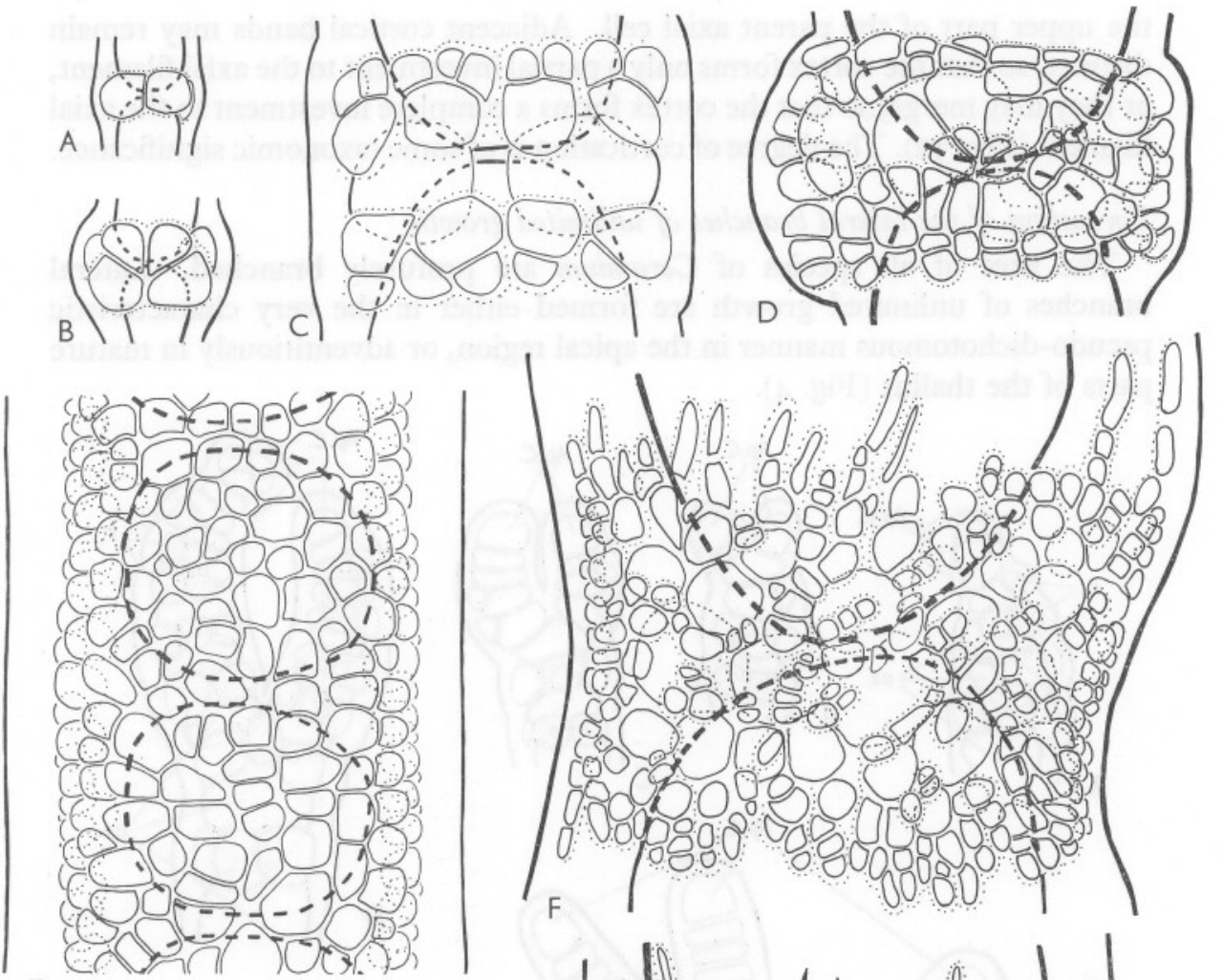

$\mathrm{E}$

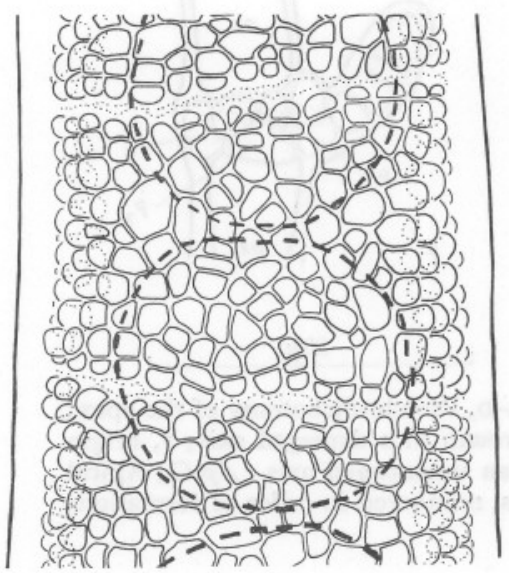

G

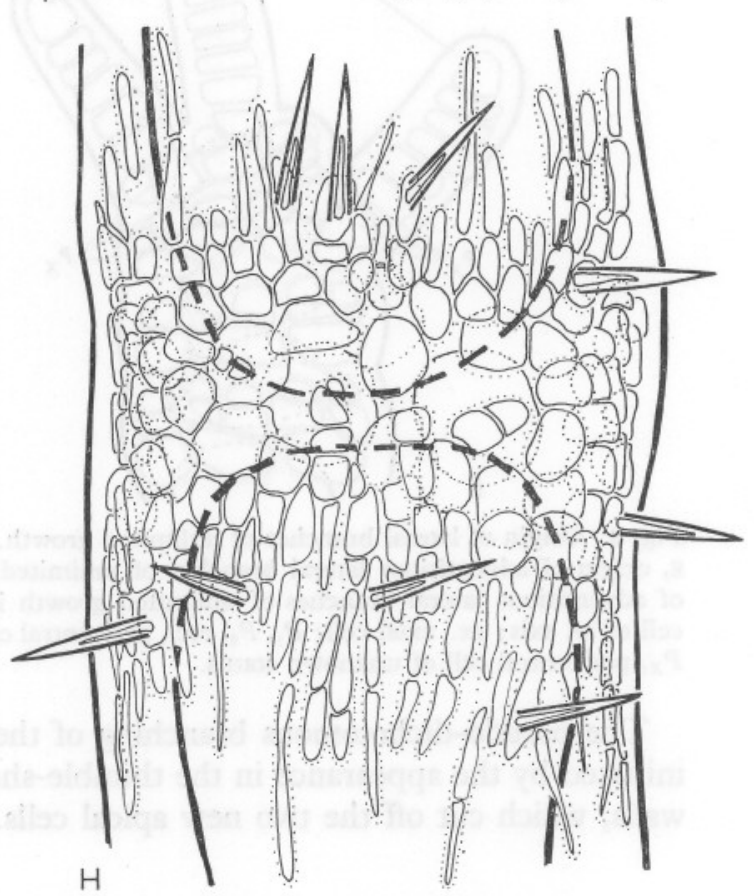

Fig. 3. A-H, Variation in the cortical band in the genus Ceramium. 
the upper part of the parent axial cell. Adjacent cortical bands may remain distinct, so that the cortex forms only a partial investment to the axial filament, or they may merge, so that the cortex forms a complete investment to the axial filament (Fig. 3E). The degree of cortication is of some taxonomic significance.

\section{Formation of the lateral branches of unlimited growth}

The axes of all species of Ceramium are profusely branched. Lateral branches of unlimited growth are formed either in the very characteristic pseudo-dichotomous manner in the apical region, or adventitiously in mature parts of the thallus (Fig. 4).

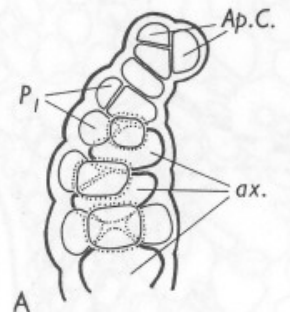

B

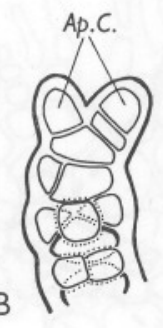

A

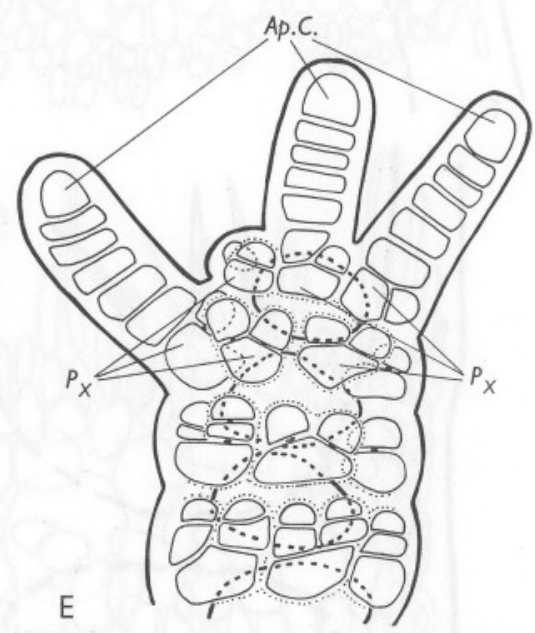

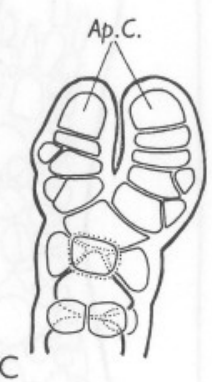

D
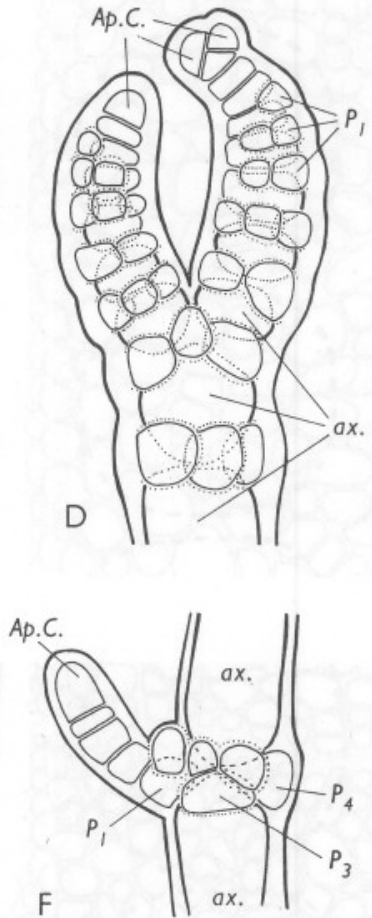

$50 \mu$

Fig. 4. Origin of lateral branches of unlimited growth. A-D, Pseudo-dichotomy of the apex; $\mathrm{E}$, origin of adventitious lateral branches of unlimited growth in a damaged axis; $\mathrm{F}$, origin of adventitious lateral branches of unlimited growth in an undamaged axis. Ap.C., Apical cell of an axis; $a x$., axial cell; $P_{1}, P_{2}$, etc., pericentral cells, numbered in order of formation; $P_{X}$, pericentral cell of unknown status.

The pseudo-dichotomous branching of the apical region of the thallus is initiated by the appearance in the thimble-shaped apical cell of two inclined walls, which cut off the two new apical cells. The first apical cell is cut off 
eccentrically on the inner face relative to the previous 'dichotomy', whilst the second apical cell is cut off on the outer face, opposite to the first (Fig. 4A, D). As a result of this orientation, the axes of the thallus tend to lie in a single plane, although secondary distortion may disturb the initial arrangement. The two new apical cells segment transversely a number of times before they undergo a further pseudo-dichotomy (Fig. 4A-D). If the growth of the pairs of derivative apical cells is balanced throughout the thallus, then the thallus has a characteristic flabellate appearance, but frequently there are differences in rate of growth between the apical cells of each pair so that the thallus is somewhat racemose.

Adventitious lateral branches of unlimited growth occur frequently in all species of the genus Ceramium. They may develop prolifically in apparently normal specimens, although they occur frequently in specimens which have been grazed by animals or damaged in some other way, and in specimens in which tetrasporangia or carposporophytes have developed.

The apical cell of an adventitious lateral branch of unlimited growth is formed by the transformation of the apical cell of a lateral branch of limited growth (Fig. 4E, F). In old, fully developed specimens, after extensive damage, adventitious lateral branches of unlimited growth may arise from any part of the thallus.

The germination of tetraspores in situ has been observed on a few occasions, in various species of Ceramium (see p. 349), although the phenomenon is not of frequent occurrence, not having been reported by previous investigators. The germlings produced by this 'internal' germination of tetraspores grow out from the parent axis and in this way give rise to a form of 'false branching'. In some examples, the attachment of the germling to the parent is firm and the tissues of the two organisms blend together almost imperceptibly so that it is very difficult to distinguish between an adventitious lateral branch of unlimited growth and the product of 'internal' germination of a tetraspore. In other cases, particularly in those species where the cortical bands form an incomplete investment to the axial filament, the germination of tetraspores in situ is very obvious and the attachment is usually very weak so that the germlings are easily detached.

\section{Hairs}

Unicellular hairs, similar to those which have been described in numerous species of the Florideae (Berthold, I882; Möbius, I892; Rosenvinge, I9II; Feldmann-Mazoyer, 1940) occur frequently in the genus Ceramium (Fig. 5 AD). The hairs occur in all parts of the thallus, but normally they are most abundant in the apical regions. A hair may develop from any superficial cell of the thallus. A small uninucleate primordium, with dense granular contents, is cut off from the superficial cell (Fig. 5B, C), which then functions as a basal cell. Rapid elongation takes place, so that when mature the hairs 
measure up to $100 \mu$ in length. During the process of elongation, the nucleus degenerates and a large vacuole is formed so that the cytoplasm forms a small, meniscus-like mass at the apex of the mature hair. The hairs are thinwalled and very fragile, so that they are easily damaged. Unlike the spines, the hairs cannot withstand desiccation, so that most are destroyed in the preparation of dried herbarium specimens.



A

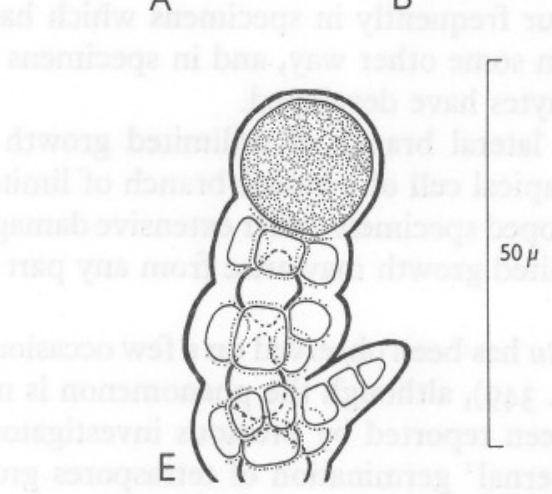

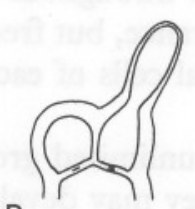

B

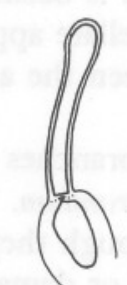

C

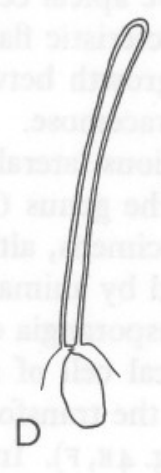

$\mathrm{F}$

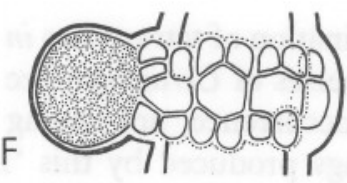

Fig. 5. A-D, Stages in the development of a hair; E, occurrence of Eurychasmidium tumefaciens in the apical cell of an axis; F, E. tumefaciens in a cell of the cortical band.

Setchell \& Gardner (1924, p. 777), in the original description of C. fimbriatum, comment on the 'single row of thick, short, unseptate hairs, which are soon deciduous, on the outer curves of the apices'. As figured by these authors (pl. 26, figs. 43, 44), these hairs are much shorter and stouter than the hairs which occur in other species of the genus. Dawson (I954, fig. 55a) also gives a figure of this species but it is somewhat crude and little information as to the nature of the hairs can be obtained from it.

\section{Glandular cells}

Glandular or vesicular cells ('cellules secretrices', 'Blasenzellen') are widespread in the Ceramiaceae (Kylin, I915, 1927; Ollivier, I927, I928; FeldmannMazoyer, 1940). In Ceramium, where they were first reported by Reinbold (I906, p. 576), they are formed by the transformation of superficial cortical cells, particularly in the apical regions of the thallus. During development, the cortical cell enlarges slightly, the nucleus and chromatophores degenerate. When mature the contents of the glandular cell are colourless and translucent. 
Degeneration takes place very rapidly so that glandular cells tend to be found principally in the apical portions of the axes.

\section{Rhizoids}

The thallus is attached to the substrate by unicellular and multicellular rhizoids (Fig. 6). In some species these are formed only at the base of the thallus, but in species of prostrate habit adventitious rhizoids develop from all parts of the plant.

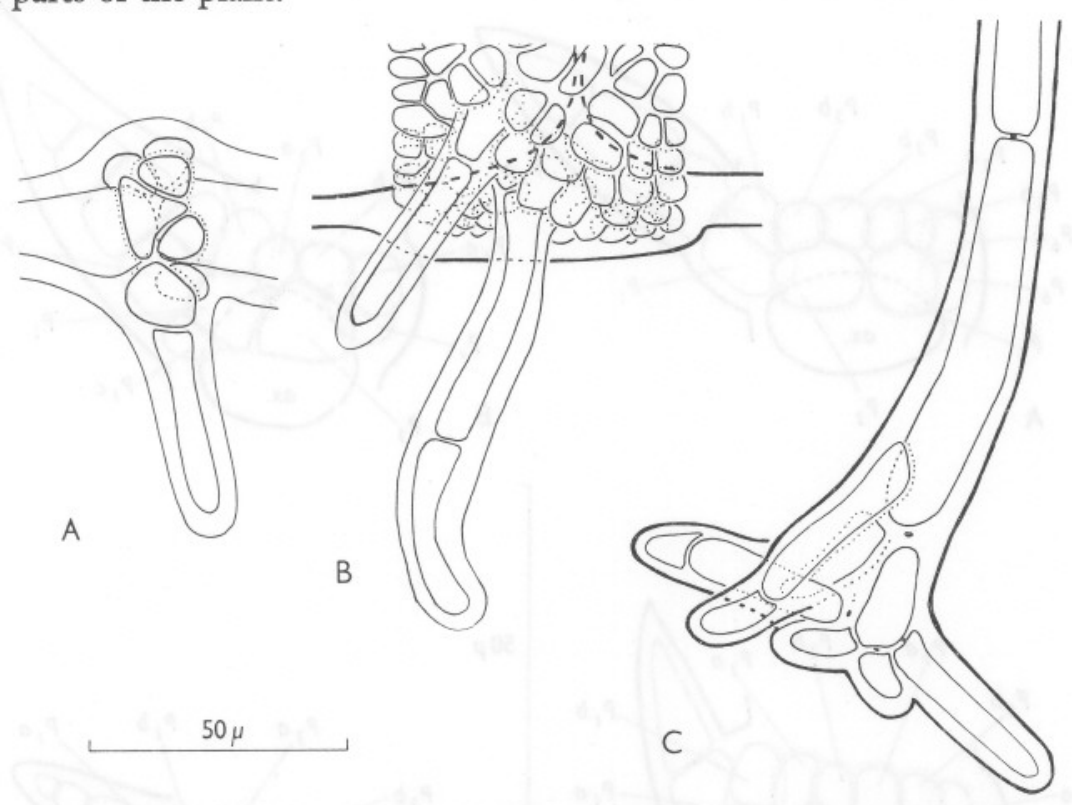

Fig. 6. A-C, Origin and structure of the rhizoids in the genus Ceramium.

The rhizoids are formed by the modification of superficial cortical cells. The primordium may remain undivided to form a unicellular rhizoid or it may divide once or twice (Fig. 6B) so that a multicellular rhizoid is formed. Occasionally a number of divisions occur at the apex of a rhizoid giving rise to a multicellular attachment organ (Fig. 6C). Unicellular rhizoids occur more frequently than the multicellular type, but both may be formed from adjacent cortical cells.

The primary basal rhizoid formed in the early stages of development of spore-germlings (see p. 349) frequently penetrates the substrate to which it is attached (Fig. 9D, E), but in most instances the adventitious rhizoids form only a superficial attachment to the substrate. There are some previous reports of the penetration of the substrate by adventitious rhizoids (FeldmannMazoyer, I940), but during the present investigation this has been observed only very infrequently. 


\section{Spines}

Spine-like structures occur in a number of species of Ceramium, of which four occur in the British Isles. In the four British species, spines develop in the meristematic apical regions of the axes, although occasionally they may be formed as adventitious structures in mature fully developed thalli. In order to differentiate between the two types of spine, the former will be referred to as 'primary spines'.
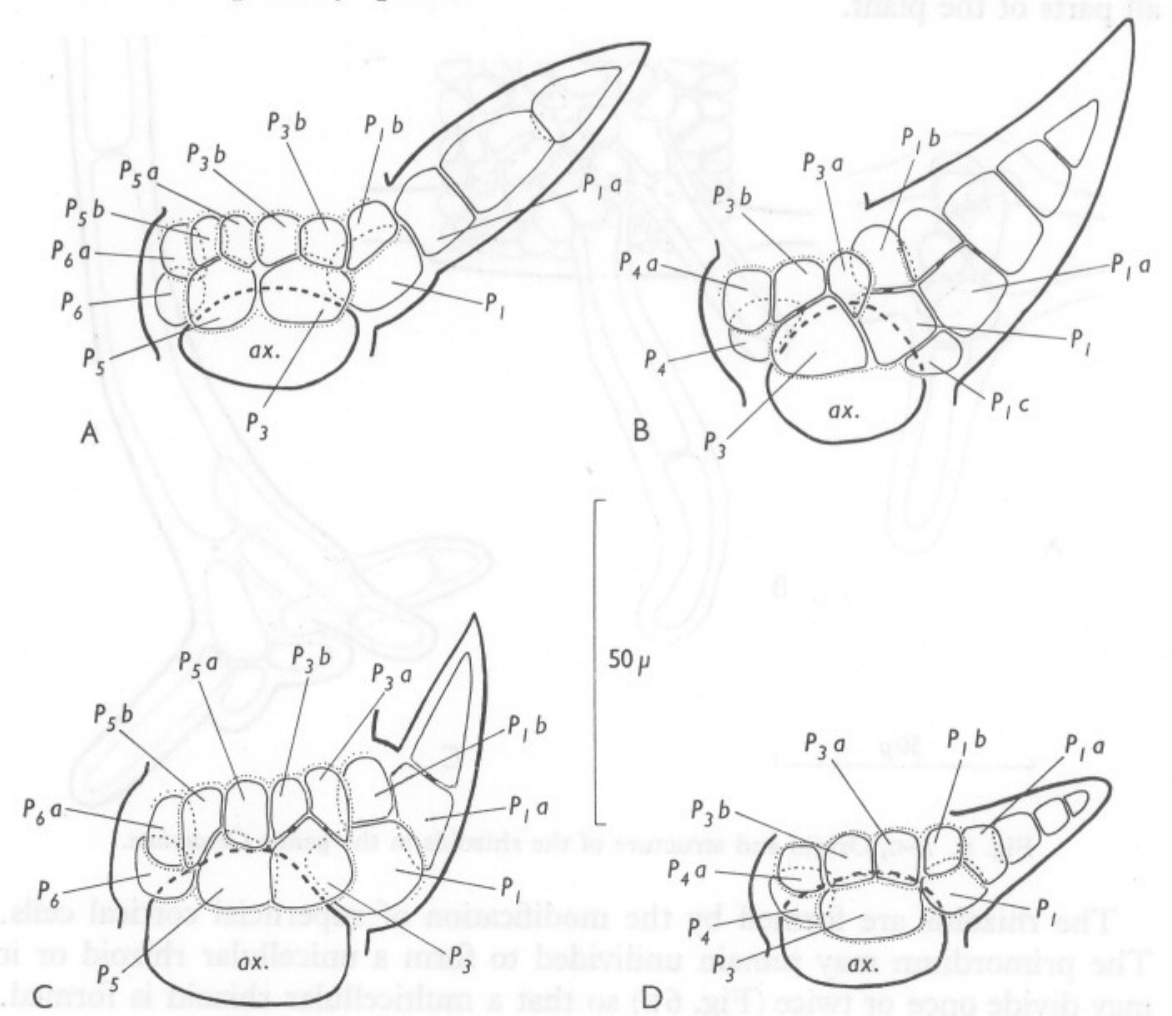

Fig. 7. A-D, The comparative morphology of the spines in the four British spine-bearing species of Ceramium. A, C. ciliatum; B, C. shuttleworthianum; C, C. echionotum; D, C. flabelligerum. ax., Axial cell; $P_{1}, P_{2}, P_{3}$, etc., pericentral cells, numbered in order of formation; $P_{1} a, P_{1} b$, acropetally directed apical cells of lateral branches of limited growth, produced from $P_{1} ; P_{2} a, P_{2} b$, acropetally directed apical cells of lateral branches of limited growth, produced from $P_{2} ; P_{1} c$, basipetally directed apical cell of lateral branch of limited growth.

A primary spine is formed by the modification of one of the two acropetal primordia of lateral branches of limited growth which develop from each pericentral cell. The degree of modification varies from species to species. In all cases, some cells at the base of the lateral branch are incorporated into the cortical band, whilst the terminal cell or cells project to form the spine. 
In $C$. echionotum the spine consists only of the terminal cell of the lateral branch of limited growth, whereas in C. ciliatum, C. shuttleworthianum and C. flabelligerum, the spine is formed from a number of cells (Fig. 7A-D). Primordia of lateral branches of limited growth which are to form spines are formed before, and grow very much more quickly than adjacent primordia. Because of this, a spine may be fully developed before the second acropetal primordium of a lateral branch of limited growth is cut off from the parent pericentral cell. The frequency of formation of spines varies considerably in the four species, but, if any spines are formed in a segment, then the firstformed will always occur on the outer face of the axis relative to the previous pseudodichotomy. If more than one primary spine is formed, these will tend to develop from acropetal primordia of adjacent pericentral cells. The conversion into spines of both the acropetal primordia of a given pericentral cell is of very rare occurrence and has been observed only twice by the present author.

Adventitious spines may develop in profusion from any part of the thallus, but they occur usually in the older, more mature parts. In structure the adventitious spines resemble the primary spines, but they are formed by the modification only of the ultimate part of a lateral branch of limited growth. Unlike the primary spines, the orientation of the adventitious spines is not determined and their arrangement is therefore very irregular (Fig. $3 \mathrm{H}$ ).

Feldmann-Mazoyer (1940, p. 153) has differentiated between the spines found in C. echionotum and those of the other species of Ceramium, claiming that the spines of $C$. echionotum are modified hairs, whilst those of other species are modified lateral branches of limited growth. The development of the spine in C. echionotum will be discussed in detail in a later publication, but it would appear that the incorrect interpretation of the spine structure in C. echionotum by Feldmann-Mazoyer results from the failure to study in detail the development of the spine in relation to the development of the cortical band. The spines of $C$. echionotum, like those of $C$. ciliatum, $C$. flabelligerum and C. shuttleworthianum, are modified lateral branches of limited growth (Fig. 7A-D).

The occurrence of spines has been reported in a number of other species of Ceramium, including: C. horridum Setchell \& Gardner (1924, p. 777), C. sinicola Setchell \& Gardner (I924, p. 773), C. paniculatum Okamura (1896, p. 36), C. hamatispinum Dawson (1950, p. 122), C. puberulum Sonder (1845, p. 52), C. monacanthum J. Agardh (1894, p. 29), C. uncinatum Harvey (1855, p. 257). The spines of $C$. monacanthum are formed by the modification of lateral branches of limited growth, but in other species the information available is so scanty that it is not possible to comment on the origin of the spines. In one or two of the species it would appear from the published figures that the term 'spine' is being used to describe short axes of unlimited growth rather than lateral branches of limited growth; further, detailed 
investigations of the morphology of the 'spine' in these species are obviously required.

\section{Galls}

Superficial gall-like outgrowths, or warts, are of frequent occurrence in the genus Ceramium. Chemin (1932) has given an account of the galls found in C. rubrum, but apparently he failed to appreciate either the frequency of occurrence of these structures or the taxonomic implications of his observations. Galls have been observed in almost all the British species of the genus during recent investigations (Dixon, unpublished).

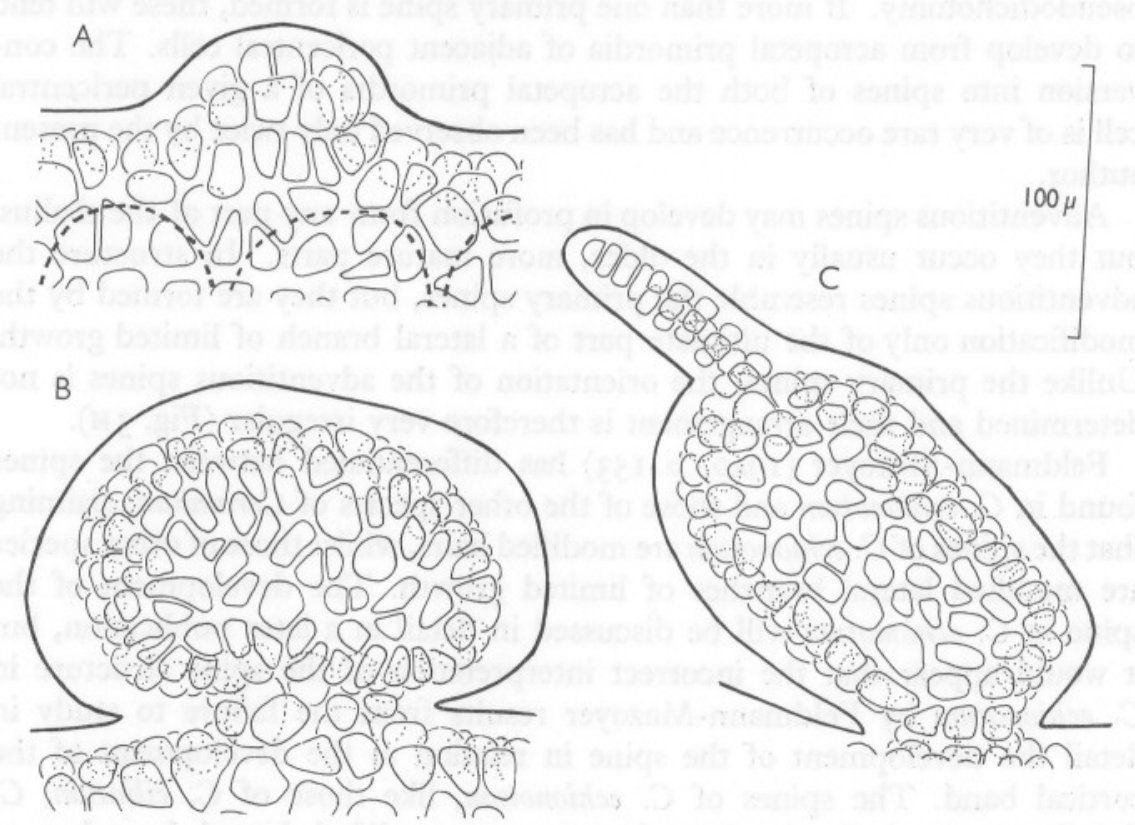

Fig. 8. A, Early stage of development of a gall; B, later stage of development; $\mathrm{C}$, axis differentiating from the tissues of a gall.

Galls occur with varying frequency; some specimens of Ceramium may show only a single example, whilst others may be covered with them. All stages of development may occur and it is obvious from a study of their development that these structures are nothing more than proliferations of the outermost cells of the cortex. During the early stages of development (Fig. 8A) the galls are hemispherical, with a smooth surface, but with age the surface becomes corrugated and in the oldest specimens the proliferations are irregularly lobed. The cells at the periphery of the gall are similar in appearance and size to those of the outermost layers of the cortex, whilst the internal cells are large and often hyaline. In those species of Ceramium in 
which spines are formed, spines may develop also from the surface of the proliferation. This phenomenon appears to have been overlooked by previous investigators, although Kützing (I862, pl. 95b, $d$ ) does give figures of what appear to be galls covered with spines, in C. monile $(=$ C. puberulum $)$. Hairs,

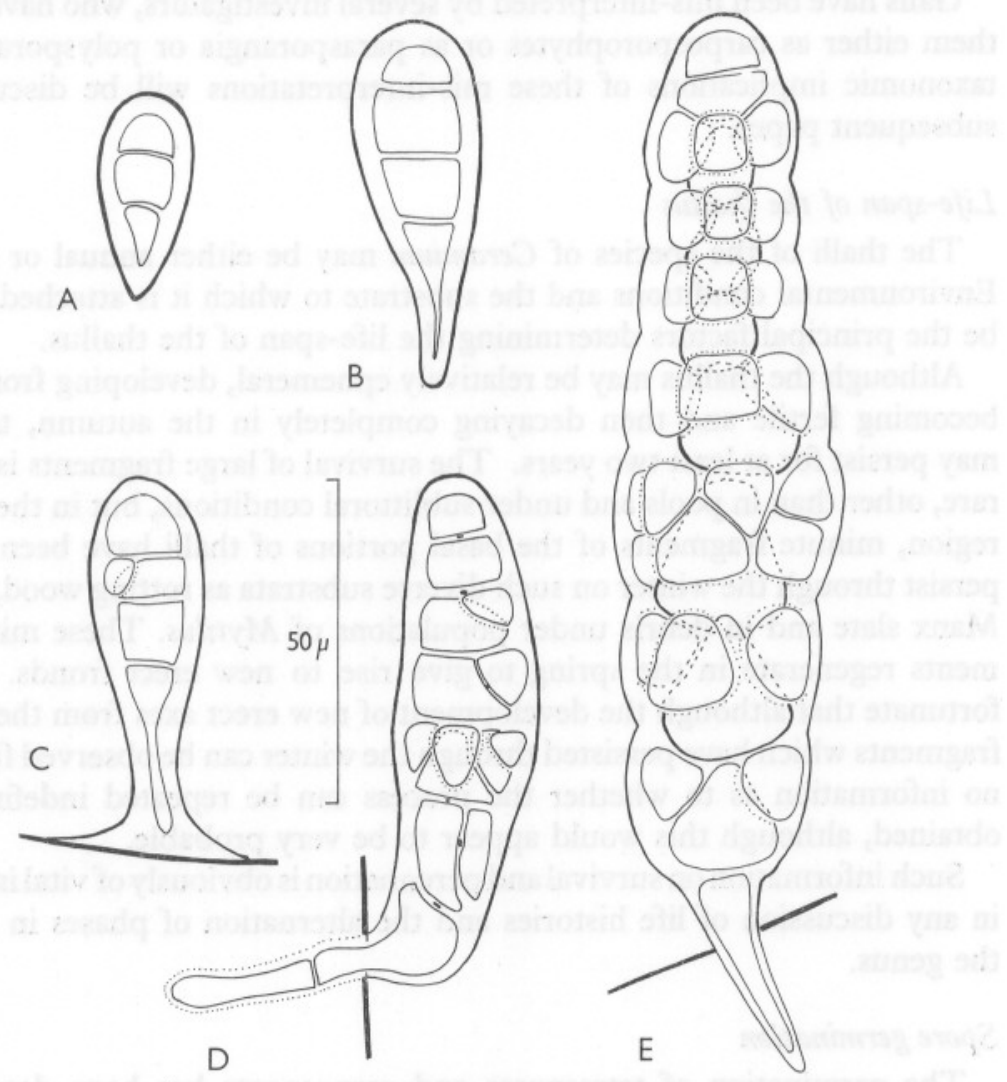

Fig. 9. A-E, Stages in spore germination.

similar to those which develop on the cortical bands, are of frequent occurrence. In one specimen the proliferations were giving rise to structures which resembled normal rhizoids and in another to an axis of unlimited growth (Fig. 8c). The galls are deeply pigmented, red or brown in colour. The largest measure up to $\mathrm{I} \mathrm{mm}$ in diameter and are clearly visible to the naked eye.

Cantacuzene (1930), as a result of a long investigation of the galls of Saccorhiza polyschides and Chondrus crispus, has shown that a bacterium occurs in the proliferations of these two species and that similar structures may be produced by inoculation of a culture of this bacterium. Chemin (1932) was unable to offer any explanation for the origin of the proliferations of C. rubrum. 
It has not been possible to determine the reasons for the development of galls during recent investigations (Dixon, unpublished). No evidence of external damage could be detected even in the youngest examples, neither could the presence of bacteria be detected in fresh or preserved material.

Galls have been mis-interpreted by several investigators, who have regarded them either as carposporophytes or as parasporangia or polysporangia. The taxonomic implications of these mis-interpretations will be discussed in a subsequent paper.

\section{Life-span of the thallus}

The thalli of the species of Ceramium may be either annual or perennial. Environmental conditions and the substrate to which it is attached appear to be the principal factors determining the life-span of the thallus.

Although the thallus may be relatively ephemeral, developing from a spore, becoming fertile and then decaying completely in the autumn, the thallus may persist for at least two years. The survival of large fragments is relatively rare, other than in pools and under sublittoral conditions, but in the intertidal region, minute fragments of the basal portions of thalli have been shown to persist through the winter on such diverse substrata as rotting wood, concrete, Manx slate and in debris under populations of Mytilus. These minute fragments regenerate in the spring to give rise to new erect fronds. It is unfortunate that although the development of new erect axes from these minute fragments which have persisted through the winter can be observed frequently, no information as to whether the process can be repeated indefinitely was obtained, although this would appear to be very probable.

Such information on survival and perennation is obviously of vital importance in any discussion of life histories and the alternation of phases in species of the genus.

\section{Spore germination}

The germination of tetraspores and carpospores has been described for various species of Ceramium (Derick, I899; Tobler, 1903; Killian, 1914; Kylin, I917; Chemin, 1937). All germlings, derived from either carpospores or tetraspores, are of the bipolar type characteristic of the Ceramiaceae. The differences between carpospore and tetraspore germination are insignificant. Little or nothing is known of the germination of the so-called 'polyspores' or 'paraspores'; the only information available is the figure given by Schiller (1913) which is indistinguishable from a similar stage of germination of a carpospore or tetraspore.

In most cases the spore attaches itself to the substrate by a cushion of mucilage and divides to form a principal apical cell and a rhizoid rudiment. The apical cell segments rapidly to form an axis whilst the rhizoid rudiment elongates to form the down-growing basal rhizoid. The rhizoid usually 
penetrates the mucilage cushion and it frequently grows into the substrate if this is of suitable texture (Fig. 9D, E). The segments produced by the division of the principal apical cell give rise to axial cells and cortical bands in the usual way. Frequently the first-formed cortical bands are slightly aberrent in that development of the band is somewhat restricted, although the pattern of segmentation is normal. In spine-bearing species, the spines may be malformed or even absent in the lowermost segments. The first pseudodichotomy occurs after 12 or even 18 segments have been produced, even in species where only 6 or 7 segments are normally formed between successive 'dichotomies'. At this stage of development, adventitious rhizoids develop from the lowermost cortical bands aiding the attachment to the substrate.

Although not reported by previous investigators, the germination in situ of both carpospores and tetraspores has been noted. Previously, it would appear that germination of carpospores in situ has been reported only in genera where the carposporangia are enclosed in a compact sterile envelope, i.e. Bonnemaisonia (Drew, I949), Lemanea (Mullahy, I952). In Ceramium, where the carposporangia are exposed and the carpospores more easily liberated, such germination in situ is surprising, but in a number of examples, the preliminary elongation of the carpospores has been noted and even the formation of the first division wall.

The germination of tetraspores in situ occurs more frequently. The mode of division is identical with that of liberated spores, the germlings produced growing epiphytically on the parent axis to produce a type of 'false branching'. The occurrence of such 'false branching' may or may not be very obvious and the rigidity of the attachment of the germling to the parent varies considerably. The occurrence of 'false branching' resulting from the internal germination of tetraspores is easily detected in incompletely corticate thalli, because of the very obvious disturbance of the cell arrangement in the cortical bands. Furthermore, in incompletely corticate thalli the attachment is extremely weak, so that the majority of the germlings are easily detached. In completely corticate thalli, germlings resulting from the germination of tetraspores in situ are frequently attached very firmly so that they resemble normal adventitious axes. Occasionally, because of the disturbance of the pattern of segmentation of the parent axis, their origin is obvious, but in most cases detailed microscopic examination is necessary before the product of germination of a tetraspore in situ can be distinguished from an adventitious lateral branch of unlimited growth.

In Ceramium, the proliferations produced by the internal germination of a tetraspore appear to develop each from a single spore and, without exception, all the examples studied were sterile. Osterhout (1896) has given an account of the in situ germination of tetraspores in Rhabdonia (= Agardhiella) tenera, but in this species the germlings are formed, apparently, by the aggregation of the segmentation products of all the four spores of the original tetra- 
sporangium. Furthermore, Osterhout has reported the occurrence on the proliferations in Rhabdonia of spermatangia and 'cystocarps' as well as tetrasporangia, in addition to the occurrence of all three types of reproductive structure on the one proliferation; it is obvious that a more detailed examination of Rhabdonia is necessary.

The frequency of occurrence of internal tetraspore germination in Ceramium varies considerably. A few examples were noted from time to time, but occasionally a plant would be collected in which the majority of tetrasporangia had germinated internally. It is not possible to offer any explanation for this phenomenon.

The germination of tetraspores in situ is of considerable importance in any discussion of the occurrence of tetrasporangia and sexual organs on the same thallus. Although Osterhout (I896) commented that ' proliferations resembling those of Rhabdonia occur on tetrasporic plants of Cystoclonium, Gracilaria and other higher Florideae', subsequent investigators appear to have ignored or overlooked the possibility of internal germination of tetraspores in these and other genera of the Florideae.

\section{STRUCTURE AND DEVELOPMENT OF THE REPRODUCTIVE ORGANS AND CARPOSPOROPHYTE}

Sexual and tetrasporic plants, which are morphologically identical, have been described for most species of Ceramium. According to Kniep (1928), most species are dioecious, although Rosenvinge (I924) has reported the occurrence of spermatangia on carpogonial plants of $C$. fruticulosum and a single monoecious plant of $C$. pedicillatum was detected in material collected by Dr J. A. Kitching at Lough Ine, Ireland. The life history is interpreted generally as a regular sequence of sexual, carposporic and tetrasporic phases, but there is little direct evidence to support this assumption (Petersen, 1928; Westbrook, 1935). As in other genera of the Ceramiaceae (Kniep, 1928; Drew, 1944), there have been reports of the occurrence of sexual organs and tetrasporangia on the same thallus, as follows:

C. ciliatum, tetrasporangia and carposporophytes (Woronichin, 1909)

C. circinatum, spermatangia and tetrasporangia (De Toni, 1922)

C. pedicillatum, tetrasporangia and sexual organs (Davis, I910)

C. rubrum, tetrasporangia and sexual organs (Davis, 1905).

It should be noted that in a number of species tetrasporic plants have a much wider distribution, extending further to the north, than the sexual plants. Accessory methods of reproduction ('polysporangia' and 'parasporangia') occur in a number of species, whilst Chemin (1928) and other authors have described vegetative propagation. 


\section{Tetrasporangia}

The tetrasporangia of Ceramium are produced in the cortical bands, developing laterally from cells of the lateral branches of limited growth. The number of tetrasporangia formed in a given cortical band varies considerably. In those cortical bands where a single tetrasporangium develops, it is formed always in the second position, that is, on the outer face of the axis relative to the previous 'dichotomy'. In most species, however, a number of tetrasporangia are produced in each cortical band, distributed in a whorl, or, where the number is excessively large, irregularly arranged (Fig. 10).

A


Fig. I0. A-D, Arrangement of tetrasporangia in the genus Ceramium. 
The primordia of tetrasporangia are relatively small, but when mature the tetrasporangia measure $30-1 \mathrm{IO} \times 20-60 \mu$. The division is usually tetrahedral, although a cruciate arrangement of tetraspores has been reported in a number of species (cf. Rosenvinge, I924, p. 373). In the British Isles, the cruciate arrangement occurs frequently in certain species (Fig. IOA).

The degree of emergence of the mature tetrasporangium from the cortical band is determined by the size of the sporangium and the extent of development of the band (Fig. IOA-D). In those species with continuous cortication, the tetrasporangia tend to be immersed completely (Fig. IOD), whilst in those species with interrupted cortication, they are partially emergent. Where the development of the cortical band is extremely restricted, as in C. codii, the tetrasporangia appear to be produced externally from it (Fig. IOA).

\section{Spermatangia}

The spermatangia of Ceramium have been studied repeatedly (Buffham, I884, I888; Petersen, I908; Grubb, I925; Feldmann-Mazoyer, I940).

The spermatangia are formed superficially from mother-cells derived from the apical cells of the lateral branches of limited growth. In those species where the cortex is well developed, the apical cells are transformed directly into spermatangial mother-cells, but in $C$. codii (see Feldmann-Mazoyer, I940, fig. 59 b), and in other species where the cortical band is poorly developed,

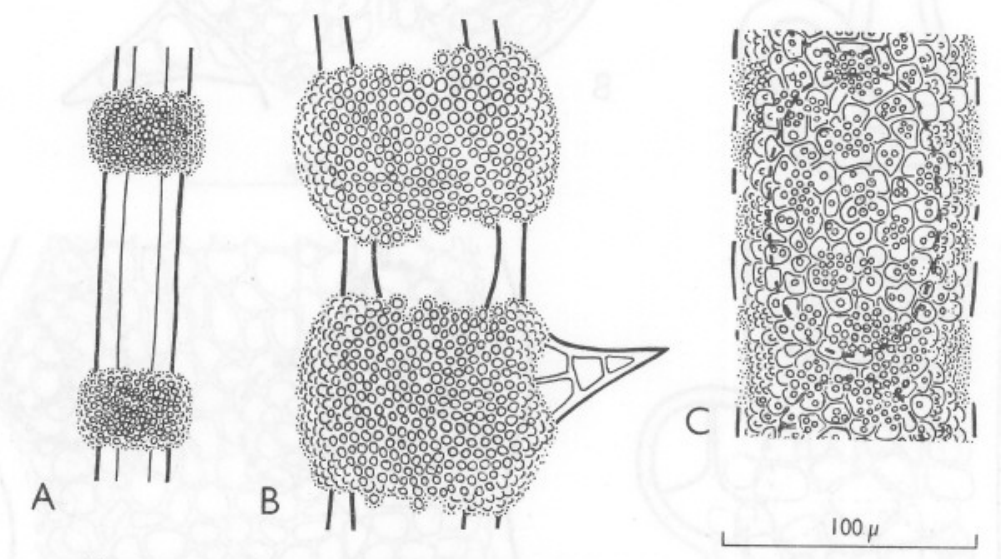

Fig. Ir. A-C, Arrangement of spermatangia in the genus Ceramium.

the apical cells of the lateral branches of limited growth divide once or twice before giving rise to spermatangial mother-cells. Each spermatangial mothercell forms from three to five spermatangia, each of which produces a single spermatium.

The spermatia are colourless and the pale patches formed by the aggregation of spermatangia are very characteristic. Where the cortical bands are 
distinct, the entire surface of each band is covered with spermatangia, but where the cortical bands are confluent, the spermatia tend to form patches of irregular outline (Fig. II).

\section{The carpogonial branch and the development of the carposporophyte}

Although the carpogonial branch and carposporophyte of Ceramium have been investigated repeatedly (Janczewski, I876; Phillips, I897; Kylin, 1923; Rosenvinge, I924; Miranda, I929 $a, b$; Dammann, 1930) the details of their development given by the different authors are somewhat contradictory. Many of the accounts are fragmentary and it may be that the confusion results from the inadequate examination of a number of different species. A full investigation of the structure and development of the carpogonial branch and carposporophyte throughout the genus Ceramium is urgently required.

In all investigated species of Ceramium, a pericentral cell functions as the supporting cell of the carpogonial branch. As far as can be ascertained, the supporting cell is always derived from the first-formed pericentral cell of a segment, so that the carpogonial branch develops in the second position, that is on the outer face of the axis relative to the previous 'dichotomy'. In sexual thalli, the carpogonial branches are produced intermittently. Frequently, the first-formed pericentral cells from a number of adjacent segments in an axis are converted into supporting cells; such fertile regions occur at intervals along the axes separated by sterile regions. The number of supporting cells produced in depauperate specimens is reduced considerably, so that carpogonial branches occur only at infrequent intervals.

As in all Ceramiaceae, the carpogonial branch is four-celled. The carpogonium is relatively small, but the trichogyne reaches a length of up to $50 \mu$. The cells of the carpogonial branch are smaller than the adjacent cells of the cortical band. The conversion of the first-formed pericentral cell into the supporting cell and the formation of one or more carpogonial branches disrupts the regular pattern of development of the cortical band. A supporting cell is larger than the normal first-formed pericentral cell from which it is derived and only one or two of the four lateral branches of limited growth normally formed from a pericentral cell are produced by a supporting cell. As a result of the disturbance of the pattern of segmentation, the position of a carpogonial branch can be detected relatively easily. It should be noted that the hairs, which may bear a superficial resemblance to trichogynes, are merely added to the normal vegetative structure, with no disturbance at all.

According to Kylin (I923, p. 63) a single carpogonial branch is formed from each supporting cell in C. rubrum, although in material of this species from the Channel Islands (Dixon, unpublished), the formation of two carpogonial branches from the same supporting cell was observed in a number of specimens. Janczewski, Phillips and Rosenvinge have reported the occasional formation of two carpogonial branches in other species of the genus. 
A detailed study has been made of the development of the carpogonial branch in a species of the C. diaphanum/strictum complex (sensu Feldmann-Mazoyer, I940), collected near Prah Sands, Cornwall. In this material, the formation of two carpogonial branches from a supporting cell occurred frequently (Fig. I2B), but such supporting cells were intermixed with others from which only a single carpogonial branch had developed (Fig. I2C, D). No explanation can be offered to account for this phenomenon.



A

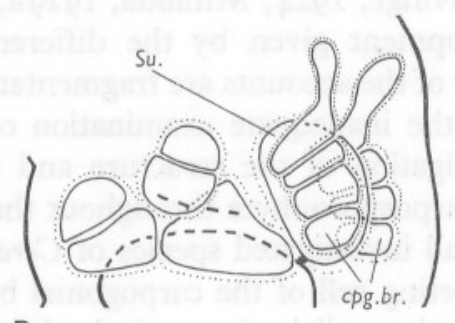

B

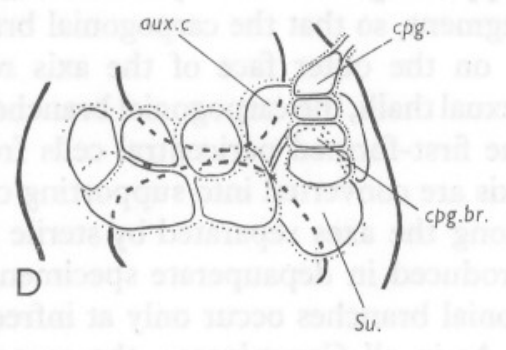

C

cpg.br.

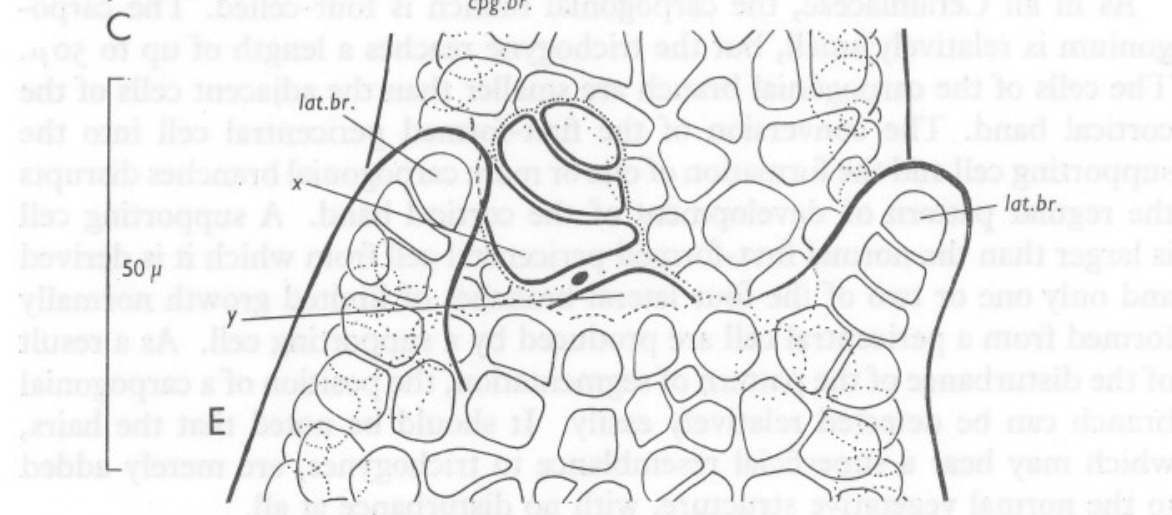

Fig. I2. A, B, Development of the carpogonial branch; c, mature carpogonial branch; $\mathrm{D}$, early post-fertilization stage; $\mathrm{E}$, initial stage in the development of the carposporophyte. aux.c., Auxiliary cell; cpg., carpogonium; cpg.br., carpogonial branch; lat.br., adventitious lateral branch of unlimited growth; $P_{1}, P_{2}$, etc., pericentral cells, numbered in order of formation; $P_{1} a$, acropetally directed apical cell of lateral branch of limited growth, produced from $P_{1} ; S u$., supporting cell, formed by the modification of the first-formed pericentral cell; $t$., trichogyne; $x$., $y$., cells at the base of the carposporophyte, whose origin cannot be stated with certainty. 
As in all Ceramiaceae, the auxiliary cell is cut off from the supporting cell subsequent to fertilization (Fig. I2D).

Details of the development of the carposporophyte are a little confused. Various authors have given a few observations on stages of development in certain species, but the absence of an over-all survey of carposporophyte development throughout the genus is a serious deficiency. Taking into account both personal observations and the descriptions of previous authors, it is possible to summarize the information available in a general way. It is thought that communication is established between the carpogonium and the auxiliary cell, and that subsequently one or more primordia are formed from the auxiliary cell. There are differences of opinion (cf. Kylin, 1923; Miranda, $\mathrm{I} 929 \mathrm{~b}$ ) as to whether the auxiliary cell divides into two cells before the formation of primordia. The further development of the carposporophyte results from the segmentation of these primordia. Fusions between certain cells have been reported by most previous investigators, but it must be stated that there is some evidence from personal observations to indicate that the fusions are not obligatory and that the cells involved are not always determined specifically. It is obvious that careful and detailed investigations are necessary for the solution of these problems.

The young carposporophyte forms a cluster of cells on the surface of the thallus (Fig. 12E). Because of the orientation of the carpogonial branches, the carposporophyte frequently lies on the outer side of the axis relative to the previous 'dichotomy'. The carposporophyte is situated usually in a small depression in the side of the axis (Figs. I2E, I3A, B), resulting from the diminished enlargement of the adjacent axial cells and the absence of some of the lateral branches of limited growth from the pericentral cell which developed into the supporting cell. As the carposporophyte enlarges, adventitious lateral branches of unlimited growth are formed from filaments of limited growth of the segment below it. The number of adventitious axes thus formed is often very characteristic, for instance in C. shuttleworthianum a single adventitious axis is produced, whilst in other species up to five or even seven such axes may be formed. The growth of these axes is restricted so that they rarely exceed $2 \mathrm{~mm}$ in length. When fully mature, the carposporophyte is encircled by these axes which form a loose, incomplete involucre.

\section{Accessory methods of reproduction}

Sporangia containing more than four spores, to which the terms 'polysporangium' and 'parasporangium' have been applied, have been reported in several species of Ceramium. Throughout the Florideae, the application of these terms is extremely confused. Schiller (1913) attempted to differentiate between the two types of sporangium, but in Ceramium, the system suggested by him proved to be inapplicable (cf. Rosenvinge, I924, p. 399). Drew (I937, I939), as a result of detailed cytological and morphological studies of selected 
examples of sporangia, has suggested that in the Florideae the sporangia containing more than four spores are of two categories, $(a)$ those which are not homologous with tetrasporangia and which are purely accessory, e.g. the 'parasporangia' of Plumaria elegans (Drew, 1939), (b) those which are homologous with tetrasporangia, e.g. the 'polysporangia' of Spermothamnion snyderae (Drew, 1937) and other Florideae (Westbrook, 1930), but the lack of data has prevented the general acceptance of this scheme and the terms

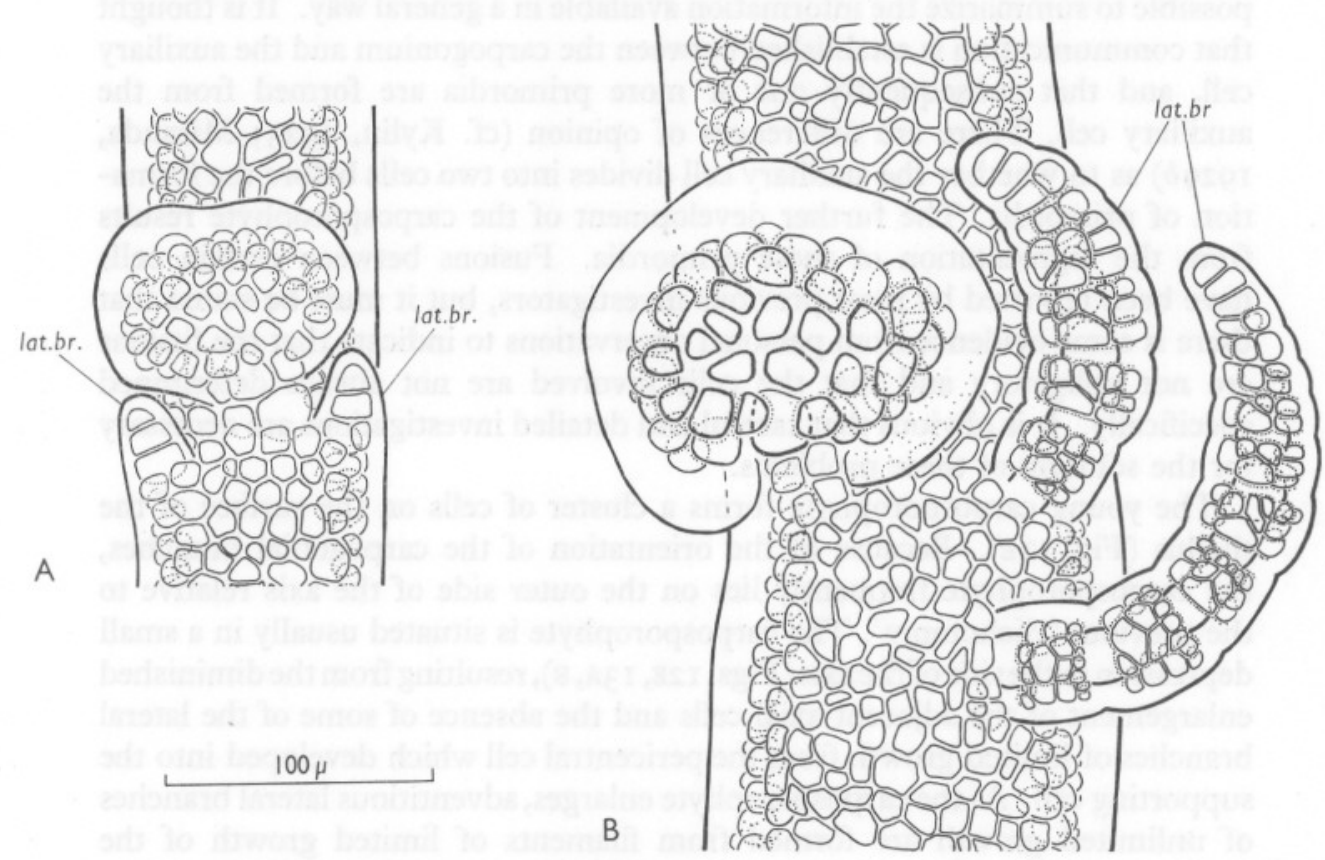

Fig. 13. A, B, Later stages in the development of the carposporophyte. lat.br., adventitous lateral branch of unlimited growth.

'polysporangium' and 'parasporangium' are still applied indiscriminately by different authors to the same structure. In the genus Ceramium the position is complicated by certain authors failing to recognize gall-like proliferations which have been misidentified and described as 'parasporangia' or 'polysporangia'. In the following account a number of descriptions have had to be discounted because of the possibility of such confusion in the absence of an illustration (e.g. Kylin, 1907).

There are two types of accessory reproductive structure in species of the genus Ceramium. These differ in structure, position and development.

Lateral sporangia, which contain from five to twelve spores, and which bear a close resemblance to tetrasporangia, have been figured in a number of species, including C. diaphanum (Petersen, 1908, figs. II and IV), C. strictum 
(Lakowitz, 1929, fig. 49I), 'C. deslongchampsii' (Rosenvinge, 1924, fig. 32I) and $C$. vertebrale (Rosenvinge, I924, fig. 325). There are no reports of the occurrence of these sporangia in the British Isles, and despite a widespread search during the past seven years, no indication of their occurrence could be found. Although little is known about the development of these lateral sporangia, from the figure given by Rosenvinge (1924, fig. 313) it would appear very probable that these sporangia should be interpreted as modified tetrasporangia and the term 'polysporangia' applied to them. A detailed cytological study of their development is urgently required. It should be noted that there is one difference between the lateral sporangia and tetrasporangia in that tetrasporangia are embedded in the cortical band, whilst the lateral sporangia are formed superficially. No information is available on the mode of germination of the 'polyspores' or of their significance in relation to the life-histories of the species in which they occur.

There have been numerous confusions between galls and the lateral 'polysporangia'. The figure of Gongroceras agardhianum given by Kützing (I862, pl. 77) has been a constant source of confusion. A study of the specimen on which this figure is based (now in the Rijksherbarium, Leiden) proves beyond doubt that the structures illustrated by Kützing are galls, but the figure has been copied repeatedly by subsequent authors (Lakowitz, I929, fig. 485; Kylin, 1937, fig. II7 D, I956, fig. 28 D; Oltmanns, 1904, fig. 425.4, I922, fig. 563.4; Schiller, I913, fig. I), the galls being described variously as 'polysporangia' or 'parasporangia'. The report by Phillips (1926) of the occurrence of 'parasporangia' in a specimen of Ceramium collected in Anglesey is also based upon a misinterpretation of galls, whilst it would appear that both van Goor (1923) and Feldmann-Mazoyer (1940) have made the same error in their interpretation of $C$. deslongchampsii. The figure of $C$. tenuissimum with 'parasporangia', given by Feldmann-Mazoyer (I940, fig. II3 p) is almost certainly based upon a gall.

It is to be regretted that the failure to detect any of these structures during extensive collecting of species of the genus Ceramium, undertaken throughout the British Isles during the last seven years, has prevented any detailed investigation of their structure, development and significance. In view of the many confusions between the galls and lateral 'polysporangia', the similarity between the few figures of the early stages of development of 'polysporangia' and the initiation of a gall and the lack of information on the development and germination of 'polyspores', the possibility that all supposed 'polysporangia' are nothing more than galls cannot be rejected.

The second type of structure, which consists of an irregularly shaped mass of spores, is formed only in an apical position. The first report of the occurrence of these structures was made by Kützing (1863, p. I, pl. I) in his account of Hormoceras acrocarpum, whilst Schiller (I9I3) has given a detailed account of their structure and development in Ceramium strictum. According to Schiller, 
the specimens occurred in an area of the Adriatic Sea where there was heavy pollution by sewage. Feldmann-Mazoyer (I940) has given a report of similar structures in $C$. diaphanum, but in the ecological notes she makes no mention of organic pollution. This type of structure does not appear to have been reported outside the Mediterranean. Nothing is known of the early stages of development, but the origin of the spore-masses by the modification of a tetrasporangium would appear to be very improbable. Schiller (1913, fig. I8) has given a figure of a young stage of germination of a spore from one of these spore-masses but the subsequent development of the germlings is unknown. Although nothing is known of their cytology or of their significance in relation to the life histories of the species in which they occur, the application of the term 'parasporangium' to these spore-masses would appear to be justified, pending a more detailed cytological and cultural investigation.

Finally, Richard (I90I), in the original description of Ceramothamnion codii (= Ceramium codii (Richards) Mazoyer), described, in addition to male and tetrasporic plants, a third type of thallus in which occurred spore-masses of a type very different from those described by Schiller. The spore-masses of Ceramium codii are subtended when mature by a group of adventitious axes, and, because of this, they bear a close resemblance to carposporophytes. The early stages of development of these spore-masses (Richards, I90I, pl. 22, figs. 17, I8) are not very clear and Richards, in the absence of any indication of a carpogonium, regarded the spore-masses as 'polysporangia'. Collins \& Hervey (I9I7, p. I34) admit that the supposed 'polysporangia' are 'quite indistinguishable from cystocarps' but state that the failure to detect the procarp is a strong argument against such an identification, although Howe (I9I8), commenting on the 'alleged polysporangia of non-sexual origin where one would naturally expect cystocarps of sexual origin', has suggested that the 'alleged polysporangia... . are in reality cystocarps'. C. codii has been reported in the British Isles (Dixon, I958), but only in a sterile condition, so that further investigation of the spore-masses, which is obviously desirable, has not been possible.

Petersen (I908, p. I4) comments briefly on the occurrence of 'monospores' in $C$. diaphanum, but the basis for this report is not at all clear. As Rosenvinge (I924, p. 374) has commented, the citation by Petersen of a figure by Gobi (1877, fig. 8) is particularly baffling. It must be admitted that Gobi's figure is not particularly well drawn, but the structures are described by him as 'Tetrasporen', and, as Rosenvinge has commented, the structures in question are tetrasporangia, the division of which is not shown.

\section{Vegetative propagation}

There is considerable experimental evidence in various species of Ceramium to show that new thalli can arise from detached fragments of the axes (Oltmanns, I895; Massart, I898; Tobler, I906; Chemin, 1928). Rhizoids develop 
adventitiously from the cells of the cortical bands so that the fragment becomes attached to the substrate, and then new apices regenerate in the manner already described (see p. 34I).

\section{FUNGAL INFECTIONS}

There are numerous records of fungal infections in species of Ceramium, but little is known of the occurrence of these fungi in the British Isles. The nomenclature adopted in the following account is based essentially on that of Sparrow (1943).

Eurychasmidium tumefaciens (Magnus) Sparrow. Magnus (1872, 1875) described and figured Chytridium tumefaciens occurring in the axes and rhizoids of Ceramium acanthonotum ( $=C$. shuttleworthianum) and C. flabelligerum. Subsequently transferred to the genera Olpidium (Wright, I879) and Pleotrachelus (Petersen, 1905), the species was ultimately made the type species of a new genus Eurychasmidium, by Sparrow (1936), because of the biflagellate zoospores. The organism studied by Sparrow occurred in the cells of the cortical band and in the apical cells of Ceramium diaphanum, but was absent from the rhizoids. It has been suggested subsequently by Feldmann \& Feldmann (1956) that two distinct fungi had been confused by Magnus (1872, 1875) in his original description of Chytridium tumefaciens. According to these authors, one organism (that studied by Sparrow) was restricted to the apical cell and the cells of the cortical band, whilst the other occurred only in the rhizoids. The latter entity was described as a new species under the name Olpidiopsis magnusii. Because of possible confusion between these two organisms, previous reports of the occurrence of Eurychasmidium tumefaciens must be regarded with caution, but it would appear that there have been no reports of the occurrence of this species in the British Isles since the early Irish record of Wright (1879). This is surprising in view of the frequency with which it has been collected on various species of Ceramium from many different localities (Dixon, unpublished). The fungal thallus develops within a superficial cell of a cortical band, or in an apical cell. The infected cell increases in size so that it forms, on the surface of the thallus, a spherical or hemispherical protuberance, which is extremely prominent due to its highly refractive contents, its thick wall and its size (Fig. $5 \mathrm{E}, \mathrm{F}$ ). Following infection of a cell of the cortical band, the development of adventitious lateral branches of unlimited growth was noted only in a few examples, but Sparrow (1936, I943) comments that in the material of $C$. diaphanum examined by him, the development of adventitious lateral branches of unlimited growth, subsequent to infection, is of very frequent occurrence, and that, as a result, the axes of the host species have a characteristic 'bushy' appearance, which is a useful indication of the site of infection. Sparrow mentions the infection of the apical cell of the host species but states that this causes little hypertrophy. In the 
British material examined, the infection of the apical cell occurred very frequently with considerable effect on the appearance of the host. Cessation of apical growth of the axes was followed, in most cases, by the development of adventitious lateral branches of unlimited growth, such as are formed whenever the apical cell of an axis is damaged or destroyed. Feldmann \& Feldmann (1956) suggest that the sites of infection of Eurychasmidium tumefaciens and Olpidiopsis magnusii are quite distinct, but from a superficial examination of the British material collected personally it would appear that this suggestion may not be fully justified. A more detailed investigation of the two supposed species and their characteristics is obviously required.

Chytridium megastomum Sparrow. Described originally by Sparrow (1934) as a parasite on Striaria attenuata, this fungus was detected subsequently at Woods Hole (Sparrow, 1936) as a parasite on Ceramium diaphanum. There is no evidence of its occurrence in the British Isles.

Pontisma lagenidioides Petersen. This fungus is restricted to species of Ceramium, occurring usually in the axial cells or the innermost cells of the cortical bands. Pontisma lagenidioides is widely distributed, occurring in various species of Ceramium: Denmark (Petersen, 1905), in C. rubrum, C. strictum and C. fruticulosum; Sweden, Gullmar Fjord (Aleem, 1955), in C. diaphanum; Germany, Kiel Bay (Höhnk, 1940), in 'Ceramium sp.'; France, Banyuls (Aleem, 1950), in C. diaphanum; France, Roscoff (Feldmann, 1954; Feldmann \& Feldmann, 1956), in C. tenuissimum; U.S.A., Woods Hole (Sparrow, 1936), in C. diaphanum. According to Sparrow (1943), Pontisma lagenidioides is found most commonly in dead or decaying material. In the British Isles it has been detected on two occasions, in a decaying specimen of Ceramium strictum collected in the drift at Port Erin, Isle of Man, and in a specimen of C. diaphanum collected in situ by Dr J. A. Kitching, at Lough Ine, Ireland.

Rhizophidium discinctum Petersen. Described originally from Scandinavia on various Chlorophyta, this species was detected subsequently on Ceramium diaphanum maintained in a laboratory aquarium for several days (Sparrow, 1936). There is no evidence of its occurrence in the British Isles.

Thrausochytrium proliferum Sparrow. Described originally by Sparrow (1936), as a saprophyte in Bryopsis plumosa and Ceramium diaphanum, there are no indications of the occurrence of this species in the British Isles.

Chytridium polysiphoniae Cohn. Cohn (1865) described this fungus as a parasite on Polysiphonia violacea; subsequently it has been detected on various marine algae, including Ceramium: Denmark, in C. rubrum, C. strictum (see Petersen, 1905); C. fruticulosum (see Sparrow, 1934); U.S.A., Woods Hole (Sparrow, 1936), in C. rubrum. Specimens probably referable to this species have been detected in the British Isles (Dixon, unpublished) on other host species, but not on species of Ceramium. According to Sparrow (1943), 
Chytridium polysiphoniae is undoubtedly a 'composite' species in need of detailed investigation.

Petersenia pollagaster (Petersen) Sparrow. Reported originally in Denmark by Petersen (1905), in Ceramium rubrum, and again by Sparrow (1934) in 'Ceramium sp.', it is very probable (teste Aleem, I955) that this species is not distinct from Petersenix lobata (Petersen) Sparrow, which has been collected from a variety of host species in Denmark (Petersen, 1905; Sparrow, 1934), the United States (Sparrow, 1936) and Sweden (Aleem, 1955). Neither entity has been detected in the British Isles.

Olpidiopsis andreei (Lagerhaim) Sparrow. There is some doubt concerning the occurrence of this fungus in Ceramium. Sparrow (1934, 1936, 1943) has reported the occurrence of a 'Pleotrachelus-like' fungus in Ceramium diaphanum, which is probably referable to Olpidiopsis andreei, whilst Aleem (I950) has identified as $O$. andreei a fungus collected in Ceramium diaphanum at Banyuls. As this species occurs most frequently in genera of the Chlorophyta and Phaeophyta, the reports of its occurrence in Ceramium should be treated with caution.

Olpidiopsis magnusii Feldmann \& Feldmann. It has been suggested by Feldmann and Feldmann that the previous reports of Eurychasmidium tumefaciens refer to two different organisms (see p. 359). These authors have separated what they consider to be the two forms and have described Olpidiopsis magnusii, as occurring in the rhizoids of Ceramium flabelligerum at Roscoff (Feldmann, 1954; Feldmann \& Feldmann, 1956). An organism similar to that described by these authors has been collected on two occasions in specimens of $C$. flabelligerum, but in addition to the infection of the rhizoids, cells of the cortical bands of these specimens were also infected, with the fungus similar to Eurychasmidium tumefaciens. Unfortunately, the specimens had been fixed before examination so that detailed study was impossible, but it is obvious that a detailed investigation of the two species and their supposed characteristics is urgently required.

Pythium marinum Sparrow. P. marinum was described originally bySparrow (1934), occurring saprophytically on Ceramium rubrum in Denmark. There is no indication for its occurrence in the British Isles.

Pythium maritimum Höhnk. Höhnk (I940) collected at Kiel a species of Pythium, growing saprophytically on 'Ceramium sp.'. From the illustration given by Höhnk (I940, fig. 4) the host species cannot be determined with certainty, but it would appear to be a species of the diaphanum/strictum complex (sensu Feldmann-Mazoyer, 1940). Höhnk claimed that this species of Pythium differed in certain respects from $P$. marinum Sparrow and it was therefore described as a new species under the name $P$. maritimum. There are no reports of the occurrence of $P$. maritimum in the British Isles. The differences between $P$. marinum and $P$. maritimum do not appear to be very significant and it is to be regretted that an authoritative opinion as to the 
status of these two entities is not available, as the description of $P$. maritimum would appear to have been overlooked in the most recent monograph of the genus (Middleton, I943).

Aleem (1955, p. 25) has given a brief account of an organism of uncertain affinity, found in the cortical cells of Ceramium rubrum, near Kristineberg, Sweden, which he compared with Pyrrhosorus marinus, described by Juel (I90I) from material of Cystoclonium purpureum from the same area. The observations of Aleem are extremely brief, being based upon a single collection, and in view of the possible complexity of the life history of this organism, the report should be treated with caution until more detailed observations are available.

\section{THE VALIDITY OF CRITERIA USED FOR SPECIFIC AND VARIETAL SEPARATION}

At the present time, the taxonomy of the genus Ceramium is in a state of chaos. This is the result of the failure of phycologists to refer back at all times to original authentic material and the failure to recognize and interpret seasonal and environmental modifications of the external form of the thallus. The search for nomenclatural type specimens is frequently a long and laborious task but, with patience, it is usually possible to locate the authentic material. In order to overcome the second difficulty, the value of the features used for the separation of species must be assessed critically. Frequently, the characters by which different supposed taxa are reputedly distinguished prove on detailed examination to have no real significance. It is obvious that a critical survey of the validity of the criteria used for specific and varietal separation is essential if these difficulties are to be overcome.

The morphological features used by previous authors for the separation of species and varieties in the genus Ceramium are as follows: (I) the number of pericentral cells, (2) the development of the cortical band, (3) the dimensions of the axial cells, (4) the 'index of cortication', (5) the occurrence of adventitious lateral branches of unlimited growth, (6) the distance between pseudo-dichotomies, (7) the curvature of the apices, (8) the spines. Each of these morphological features will now be discussed in detail.

\section{The number of pericentral cells}

From four to ten pericentral cells are formed from each segment of the apical cell of an axis of unlimited growth. The number of pericentral cells produced varies from species to species, but it is relatively constant for each species. This feature has been used by some previous investigators, but it must be applied with care, because of the slight variation which does occur. A species with seven pericentral cells, where segments with six and eight pericentral cells occur occasionally, can be distinguished readily from a second species where four pericentral cells occur constantly. 
As Phillips (1926) has stated, the number of pericentral cells can be estimated accurately only by tracing the pit-connexions with the axial cell. Usually the number of pericentral cells can be counted in a transverse section with a fair degree of accuracy, even if the pit-connexions are not located, but in old material errors may be introduced by this technique, as it is possible for a cell derived from a pericentral cell to intercalate itself into the ring of pericentral cells. Although the pericentral cells are often visible in a side-view of an axis, attempts to count them in this position are unlikely to be successful, particularly with the larger numbers.

\section{The development of the cortical band}

The appearance of the cortical band is the principal diagnostic feature in the genus Ceramium. Despite its importance, there have been no critical studies of the features controlling the development of the band and little regard for the modifying effects of season and environment. The different types of cortical construction exhibited by the various species of Ceramium can all be related to the patterns of cell division and cell enlargement occurring in the branches of limited and unlimited growth. The cortical band itself may be regarded as a cylindrical structure formed by the aggregation of the filaments of limited growth which are orientated radially as well as acropetally and basipetally.

The radial dimensions of the cortical band are determined by the degree of enlargement of the pericentral cells and their immediate derivatives, together with the extent of growth of the radially orientated filaments of limited growth. Of these two factors the former is by far the more important. The enlargement of the pericentral cells and their immediate derivatives occurs quite independently of the enlargement of the axial cells. As a result, the outline of the axes may be regularly cylindrical if the enlargement of the axial cells and the radial growth of the cortical band is balanced, or the axes may be constricted or inflated at the cortical bands if there is any marked difference between the enlargement of the one and the radial growth of the other.

The length of the cortical band produced at each segment of an axis is determined by two factors: (I) the number of divisions of the apical cells of the lateral branches of limited growth, (2) the degree of enlargement of the cells of the lateral branches of limited growth. Variation in the length of the cortical band results from variation of one or both of these factors.

In certain species, the apical cells of the lateral branches of limited growth may cease to divide at a very early stage of development, so that any increase in the length of the cortical band is caused entirely by increase in cell size. This is in fact relatively restricted, so that in these species there is very little variation in the dimensions of the cortical bands as the thallus ages. In those species where the apical cells of the lateral branches of limited growth continue 
to divide throughout the life of the thallus, there may be considerable variation in the dimensions of the cortical bands. Where the apical cells of the lateral branches of limited growth continue to divide throughout the life of the thallus, the acropetal and basipetal margins of the cortical bands are either sharply defined and parallel to one another (Fig. 3G) or very diffuse and illdefined (Fig. $3 \mathrm{H}$ ), according to whether the divisions of the apical cells take place synchronously or irregularly. Finally there may be marked differences between the growth of the acropetal and basipetal faces of a cortical band resulting from differences in the rates of cell division and cell enlargement.

It should be noted that in those species where the cortex forms a continuous investment to the axial filament, it is often difficult to ascertain the limits of the cortical bands as the lateral branches of limited growth of adjacent segments merge with one another.

In conclusion it may be stated that the appearance of the cortical band is perfectly adequate as a diagnostic character, providing that the patterns of cell division and cell enlargement are interpreted correctly.

\section{The dimensions of the axial cells}

An axial cell is derived from each segment of a principal apical cell; after the formation of pericentral cells, no further divisions occur and the resulting axial cell merely increases in size. The ultimate dimensions of an axial cell are determined by its position in the thallus and the pattern of cell enlargement is extremely complex. The dimensions of the axial cells are of obvious importance in that they determine the dimensions of the frond. In order to investigate the pattern of cell-size variation, measurements were made of every axial cell in plants of various species collected from a wide range of environments from different parts of the British Isles. Although there are considerable fluctuations in the dimensions of the axial cells, both between species, and even in the same species, the same general pattern of variation was detected in all the thalli examined.

The over-all range of size of the axial cells is shown by a comparison of the average length and volume of these cells in successive sectors of the thallus, from base to apex. In this connexion, the term 'sector' is applied to the portion of the thallus between successive 'dichotomies'. If the average length of the axial cells in each sector is calculated, the average length per sector increases from a minimum value immediately behind an apex to reach a maximum value either at or near the base of the thallus. The rate of increase of the average length of the axial cells per sector and the maximum value attained vary enormously and it is obvious that they are affected to a very great extent by the environmental conditions. The average measurements of the axial cells of the basal, first-formed, sectors of a plant are often slightly lower than the maximum size, but this decrease in size does not occur in all examples.

Measurements of the average size of the axial cell per sector, made in this 
way, do not show the very characteristic pattern of variation of cell-size within each sector. In any sector of the thallus, apart from those sectors immediately behind the principal apical cells, where all axial cells are enlarging actively, the axial cells show considerable variation in length, the smallest axial cell occurring at the basal end of the sector, that is, immediately after a 'dichotomy', whilst the largest occurs towards the opposite end of the sector (Fig. I4). In mature thalli, the largest axial cell in a sector is about twice the

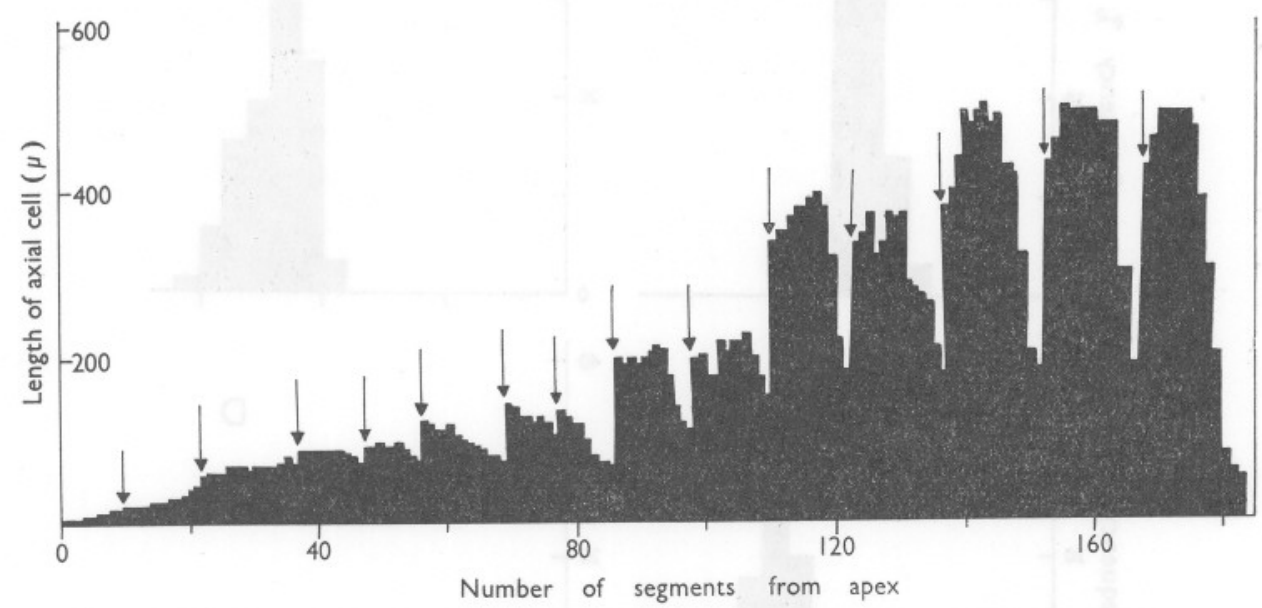

Fig. I4. Histogram showing the pattern of variation in size of the axial cells in relation to distance from the apex and the positions of pseudo-dichotomies; the position of each pseudodichotomy is indicated by an arrow.

length, or about three times the volume of the smallest. This pattern of variation is complicated by other factors, for instance, the formation of tetrasporangia or the development of adventitious lateral branches of unlimited growth may inhibit to a certain extent the enlargement of the associated axial cell. As a result, there may be small irregularities in the pattern of axial cell size, but these have no major effects on the general pattern of variation within each sector.

The interaction of the two patterns of variation of axial cell size, that is, between the sectors of a thallus and within each individual sector, is most complex (Fig. I4). It will be obvious from this that any measurements of axial cell size must be cited in relation to a particular part of a thallus, and that 'average' measurements must be based upon sufficiently large samples ( $>300$ cells).

\section{The 'index of cortication'}

In those species where the axes are incompletely corticated, the ratio of the length of the cortical band to the length of the adjacent non-corticated portion of the axial cell has been used as a taxonomic criterion. 
Those investigators who have used this ratio do not appear to have given any consideration to the significance of this feature. As has been shown previously, the factors affecting the length of the cortical band are very complex, whilst the patterns of variation of axial cell size are extremely complicated.
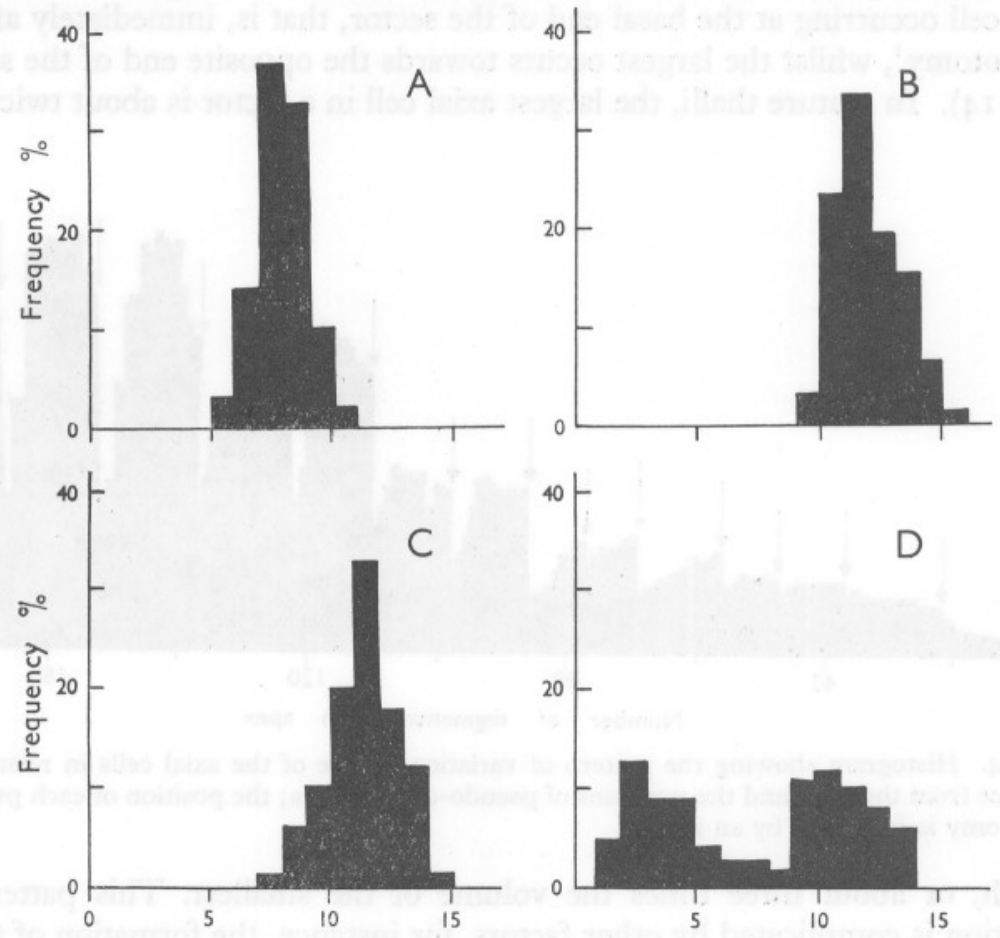

Number of segments

Fig. 15. A-D, Histograms showing the number of segments produced between successive pseudo-dichotomies in three species of Ceramium. A, C. shuttleworthianum; B, C. echionotum; c, C. ciliatum, excluding adventitious lateral branches; $\mathrm{D}, C$. ciliatum, including these branches.

Furthermore, the 'index of cortication' does not represent the direct ratio of the dimensions of the cortical band and the axial cell, as the length of the non-corticated portion of the axial cell is actually the difference of the lengths of the axial cell and cortical band. Hence, the 'index of cortication' may be represented as follows:

$$
\begin{aligned}
\text { Index of cortication } & =\frac{\text { length of axial cell non-corticated }}{\text { length of cortical band }} \\
& =\frac{\text { (length of axial cell) minus (length of cortical band) }}{\text { length of cortical band }} \\
& =\frac{\text { length of axial cell }}{\text { length of cortical band }}-\mathrm{I} .
\end{aligned}
$$


The interaction of the two patterns of variation is so very complex that significant differences in the 'index of cortication' occur in the same species, or even in the same specimen, according to the position on the thallus at which measurements are taken. As a taxonomic criterion, the 'index of cortication' is of very dubious validity.

\section{The occurrence of adventitious lateral branches of unlimited growth}

The formation of adventitious lateral branches of unlimited growth has been described previously (see p. 34I), but no explanation can be offerred to account for the occurrence of these structures. Although most frequent in damaged specimens, they may develop prolifically in axes which are apparently normal. Adventitious lateral branches of unlimited growth are formed also in tetrasporic and 'cystocarpic' specimens after the shedding of spores has commenced and immediately beneath a developing carposporophyte. Although used frequently by previous investigators, the occurrence of adventitious lateral branches of unlimited growth is of very little taxonomic significance.

\section{The distance between pseudo-dichotomies}

In certain members of the Ceramiaceae, the formation of lateral branches of unlimited growth takes place with some regularity (cf. Chadefaud, I954), but there is considerable variation in the genus Ceramium in the number of segments produced between successive pseudo-dichotomies. The measurement of the number of segments produced between successive pseudo-dichotomies (cf. Newton, I93I) is of very little significance even if the formation of adventitious lateral branches of unlimited growth is eliminated. If no distinction is made between lateral branches of unlimited growth of adventitious origin and those which have arisen by the pseudo-dichotomy of the apex, and in old specimens this is often impossible, the number of segments occurring between successive lateral branches has no taxonomic significance whatsoever.

\section{The curvature of the apices}

In some species of Ceramium, the apical portions of the axes are incurved strongly, whilst in others, the axes are straight throughout. The degree of curvature of the apical parts of the axes has been used by some previous investigators as a taxonomic criterion, particularly at the subspecific level.

The degree of curvature of the apical regions of an axis depends upon the relative rates of development of the lateral branches of limited growth in each segment. As stated previously, the first pericentral cell is formed in the secund position, that is, on the outer face of the axis relative to the previous pseudo-dichotomy. In those species in which the apices are strongly incurved, the apical cells of the lateral branches of limited growth are produced by the first-formed pericentral cell immediately after its formation. In this way, the cortical band is well established on the outer face of the axis by the time 
the final pericentral cell is cut off on the inner side (Fig. I D-F). As a result, when the final pericentral cell has been formed, each cortical band is wedgeshaped in longitudinal section, with the apices of the wedges pointing inwards, relative to the previous pseudo-dichotomy. The axes are formed by the aggregation of these wedge-shaped cortical bands and they are therefore strongly incurved. As the axes age, the eccentric development of the inner and outer faces of the cortical bands becomes less marked so that the degree of curvature diminishes until, in mature thalli, the axes are straight or almost so.

In those species of Ceramium in which the apices are straight or only very slightly incurved, the pericentral cells are cut off in rapid succession, and the further development of the filaments of limited growth does not take place until after the complete ring of cells has been formed (Fig. I A-C). The development of the cortical band is thus completely symmetrical in these species.

The degree of curvature of the apical region of an axis appears to be almost constant and is sufficiently stable to serve as a valid taxonomic criterion.

\section{The spines}

The comparative morphology of the spines in the British species of Ceramium has been discussed in detail (see p. 344). Although the spines of all the British species must be regarded as modified lateral branches of limited growth (Fig. 7A-D), the spines are very different one from another, both in structure and development. Previous confusion with regard to the morphology of the spines is the result, essentially, of the failure to study the patterns of development by which spines are formed. In the European species, the patterns of development of the different types of spine are constant and sufficiently stable to serve as a valid taxonomic criterion.

\section{DISTRIBUTION}

According to Kylin (1956), there would appear to be about sixty species of Ceramium, of which twenty are reputed to occur in the British Isles (Parke, I953). Such computations are of little significance as the taxonomy of Ceramium is in a chaotic state at the present time.

Much of this chaos has come about as a result of the failure to take notice of, and interpret, the modifying effects of season and environment upon exceedingly plastic material. The position has been made worse by the failure of many workers to refer back at all times to original or authentic material. As a result there have been numerous misidentifications, epithets have been misapplied by the majority of investigators and frequently the same entity has been described repeatedly under 'new' names by successive authors.

In this treatment of the genus Ceramium and its species, the determination of specific limits will be based entirely on morphological and ecological circumscription. 


\section{KEY TO THE BRITISH SPECIES}

It is proposed to consider the British species of Ceramium in two groups. This treatment does not imply that the groupings are considered to be of fundamental importance; the species are arranged in this way merely for convenience.

Group A. Species in which the mature axes are either completely or incompletely corticate, but where the cortical bands give rise to spines.

Group B. Species in which the mature axes are either completely or incompletely corticate, but where spines are absent.

I. Spines single-celled.

KEY TO THE SPECIES OF GROUP A

Spines two-, three- or four-celled.

C. echionotum

2. Each spine consisting of a linear row of cells, sharply delimited from the cortical band.

Each spine multicellular at the base, merging with the cortical band.

C. shuttleworthianum

3. Basal cell of spine large ( $>30 \mu$ in length), hyaline or faintly pigmented. Spines usually in whorls, very conspicuous. Pericentral cells 6 or more. C. ciliatum Basal cell of spine less than $25 \mu$ in length, deeply pigmented. Spines sparse, inconspicuous. Pericentral cells 4 .

C. flabelligerum

Note. A key to the species of group B is in preparation.

\section{ACKNOWLEDGEMENTS}

I am indebted to Dr M. T. Martin for her assistance and encouragement during the preparation of this paper; to Prof. N. A. Burges, Dr E. M. Burrows and Dr M. W. Parke for advice and helpful criticism; to Mr R. Ross for assistance with nomenclatural problems and to Mrs Y. Butler, Miss C. I. Dickenson and Dr J. Th. Koster for help with literature and specimens. I would like to thank the Joint Committee on Research of the University of Liverpool for financial help towards the cost of visiting herbaria and libraries and the Directors and Curators of the following herbaria for permission to examine specimens: British Museum (Natural History); Royal Botanic Gardens, Kew; Rijksherbarium, Leiden.

The British Phycological Society has made a grant to the Marine Biological Association towards the cost of publication of these Studies.

\section{REFERENCES}

Adanson, M., I763. Familles des plantes, II, (I8) $+640+(19-24)$ pp. Paris. Agardh, C. A., I8I r. Dispositio Algarum Sueciae, pp. 17-26. Lund.

Agardh, J. G., I894. Analecta algologica. Observationes de speciebus algarum minus cognitis earumque dispositione. Continuatio II. Acta Univ. lund., Bd. 30, Nr. 7, pp. I-99. 
Aleem, A. A., 1950. Phycomycètes marins parasites de diatomées et d'algues dans la région de Banyuls-sur-Mer (Pyrénées-Orientales). Vie et Milieu, T. I, pp. 42I40.

1955. Marine fungi from the west coast of Sweden. Ark. Bot., A.S., Bd. 3, pp. I-33.

BERTHOLD, G., I882. Beiträge zur Morphologie und Physiologie der Meeresalgen. fb. wiss. Bot., Bd. 13, pp. 569-717.

Bonnemaison, T., I822. Essai d'une classification des Hydrophites loculées, ou plantes marines articulées qui croissent en France. F. Phys. Chem. Hist. nat., T. 94 , pp. 138-48, 174-203.

Børgesen, F., 1952. Some marine algae from Mauritius. Additions to the parts previously published. IV. Biol. Medd., Kbh., Bd. I8, H. 19, pp. I-72.

— 1953. Some marine algae from Mauritius. Additions to the parts previously published. V. Biol. Medd., Kbh., Bd. 21, H. 9, pp. I-62.

BuffHAm, T. H., I884. Notes on the Florideae and on some newly found antheridia. F. Quekett micr. Cl., Ser. 2, Vol. I, pp. 337-44.

- I888. On the reproductive organs, especially the antheridia of some of the Florideae. F. Quekett micr. Cl., Ser. 2, Vol. 3, pp. 257-66.

Cantacuzene, M. A., I930. Contribution à l'étude des tumours bactériennes chez les algues marines. Arch. roum. Path. exp. Microbiol., T. 3, pp. 103-78.

Celan, M., I939a. Sur les cellules conductrices des algues rouges. Bull. Soc. bot. Fr., T. 86, pp. 297-9.

- 1939b. Sur la structure des cellules du genre Ceramium. C.R. Acad. Sci., Paris, T. 208, pp. $174 \mathrm{I}-3$.

Chadefaud, M., I954. Sur la morphologie de quelques Céramiacées. Rev. algol., N.S., T. I, pp. $71-87$.

Chemin, E., I928. Multiplication végetative et dissémination chez quelques algues Floridées. Trav. Sta. biol. Roscoff, T. 7, pp. 5-60.

- 1932. Sur l'existance de galles chez le Ceramium rubrum Ag. C.R. Soc. Biol., Paris, T. 109, pp. 155-7.

— 1937. Le développement des spores chez les Rhodophycées. Rev. gén. Bot., T. 49 , pp. 205-34, 300-27, 353-74, 424-48, 478-536.

CoHn, F., I865. Chytridii species novae marinae. Hedwigia, Bd. 4, pp. I69-70.

Collins, F. S. \& Hervey, A. B., I917. The algae of Bermuda. Proc. Amer. Acad. Arts Sci., Vol. 53, pp. I-r95.

Cramer, C., 1857. Monographie der Ceramieen, in Pflanzenphysiologische Untersuchungen, H. 4 , pp. I-I3I.

DAMMANN, H., 1930. Entwicklungsgeschichtliche und zytologische Untersuchungen an Helgoländer Meeresalgen. Wiss. Meeresuntersuch., Abt. Helgoland, Bd. I8, H. 4, pp. I-36.

— 1932. Beitrag zur Kenntnis der Zentralzellen der Gattung Ceramium. Ber. dtsch. bot. Ges., Bd. 50, pp. 68-72.

Davis, B. M., I905. Studies on the plant cell. V. Cell activities at critical periods of ontogeny in plants. Amer. Nat., Vol. 39, pp. 449-99.

- I910. Nuclear phenomena of sexual reproduction in algae. Amer. Nat., Vol. 44, pp. 513-22.

Dawson, E. Y., I950. A review of Ceramium along the Pacific coast of North America with special reference to its Mexican representatives. Farlowia, Vol. 4, pp. II3-38. 1954. Marine plants in the vicinity of the Institute Oceanographique de Nha Trang, Viêt Nam. Pacif. Sci., Vol. 8, pp. 373-469.

DERICK, C. M., I899. Notes on the development of the holdfasts of certain Florideae. Bot. Gaz., Vol. 28, pp. 246-63. 
De Toni, G. B., I922. Materiali per la fenologia degli organi di riproduzione delle Florideae mediterranee. Mem. R. Com. talassogr., Vol. 89, pp. I-40.

Dixon, P. S., 1958. Ceramium codii (Richards) Mazoyer: an addition to the British marine algal flora. Ann. Mag. nat. Hist., Ser. 13, Vol. 1, pp. I4-16.

Donati, V., 1758. Essai sur l'histoire naturelle de la mer adriatique.... iv $+73 \mathrm{pp}$. La Haye.

DREw, K. M., I937. Spermothamnion snyderae Farlow, a Floridean alga bearing polysporangia. Ann. Bot., Lond., N.S., Vol. I, pp. 463-76.

- 1939. An investigation of Plumaria elegans (Bonnem.) Schmitz with special reference to triploid plants bearing parasporangia. Ann. Bot., Lond., N.S., Vol. 3, pp. 347-67.

- 1944. Nuclear and somatic phases in the Florideae. Biol. Rev. Vol. 19, pp. I05-20. 1945. A hitherto undescribed form of adult axis in the genus Batrachospermum. Nature, Lond., Vol. 155, p. 608.

- 1949. In situ development of carpospores of Bonnemaisonia asparagoides. Nature, Lond., Vol. 163, p. 253.

EHRENBERG, C. G., I844. Einige vorläufige Resultate seiner Untersuchungen der ihm von der Südpolreise des Capitain Ross, sowie von den Herren Schayer und Darwin zugekommenen Materialen.... Mber. Berl. Akad. Wiss., 1843/4, pp. 182-207.

FELdMANN, J., 1954. Inventaire de la flore marine de Roscoff. Trav. Sta. biol. Roscoff (Suppl. 6), I52 pp.

Feldmann, J. \& Feldmann, G., 1946. Recherches sur l'appareil conducteur des Floridées. Rev. Cytol., Paris, T. 8, pp. 159-209.

—_ 1956. Observations sur quelques Phycomycètes marins nouveaux ou peu connus. Rev. Mycol., Paris, T. 20, pp. 23I-5I.

Feldmann-Mazoyer, G., 1940. Recherches sur les Céramiacées de la Mediterranée occidentale. 5 ro pp. Alger.

— 1952. Ceramium. In Børgesen, F., 1952, Some marine algae from Mauritius. Additions to the parts previously published. IV. Biol. Medd., Kbh., Bd. I8, H. I9, pp. I-72.

FrITSCH, F. E., I945. The Structure and Reproduction of the Algae. Vol. II. xiv + 939 pp. Cambridge.

FunK, G., 1955. Beiträge zur Kenntnis der Meeresalgen von Neapel.... Pubbl. Staz. zool. Napoli, Vol. 25 (Suppl.), x+ 178 pp.

Gaertner, J., I788. De fructibus et seminibus plantarum. Accedunt seminum centuriae quinque priores cum tabulis aeneis $L X X I X$, (12) + clxxxii $+384+(7) \mathrm{pp}$. Stuttgart.

GobI, C., I877. Die Rothtange (Florideae) des Finnischen Meerbusens. Mém. Acad. Sci. St-Pétersb. (Sci. math., phys., nat.), Sér. 7, T. 24, F. 7, pp. I-I6.

van Goor, A. C. J., 1923. Die holländischen Meeresalgen.... Verh. Akad. Wet. Amst., Sekt. 2, Bd. 23, pp. I-232.

Greville, R. K., I830. Algae britannicae, or descriptions of the marine and other inarticulated plants of the British Isles, belonging to the order Algae. Ixxxviii +218 pp. Edinburgh.

GrubB, V. M., 1925. The male organs of the Florideae. F. Linn. Soc. (Bot.), Vol. 47, pp. $177-255$.

HaRvey, W. H., I855. Algae. In Hooker, J. D., The Botany of the Antarctic voyage. Pt. II. Flora Novae Zelandiae, Vol. 2, pp. 2 I I-66.

Hick, T., I884. On protoplasmic continuity in the Florideae. F. Bot., Lond., Vol. 22, pp. 33-8, 65-71.

HöHNK, W., 1940. Ein Beitrag zur Kenntnis der Phycomyceten des Brackwassers. Kieler Meeresforsch., Bd. 3, pp. 337-61. 
Hooker, J. D. \& HARvey, W. H., r848. Algae Novae Zelandiae (Supplementum primum). Lond. F. Bot., Vol. 7, pp. 443-5.

Howe, M. A., 1914. The marine algae of Peru. Mem. Torrey bot. Cl., Vol. 15, pp. $\mathrm{I}-\mathrm{I} 84$.

- 1918. Algae. In Britton, N. L., Flora of Bermuda, 585 pp. New York.

Hudson, W., 1762. Flora anglica, exhibens Plantas per regnum Angliae sponte crescentes. $\mathrm{xv}+506 \mathrm{pp}$. London.

JANCZEWSKI, E., I876. Notes sur le développement du cystocarpe dans les Floridées. Mém. Soc. nat. Sci. Cherbourg, T. 20, pp. 109-44.

Juel, H. O., I901. Pyrrhosorus, eine neue marine Pilzgattung. Bih. svensk. VetenskAkad. Handl., Bd. 26, H. I4, pp. I-I6.

Killian, C., I9I4. Ueber die Entwicklung einiger Florideen. Z. Bot., Bd. 6, pp. $209-78$.

KNIEP, H., I928. Die Sexualität der niederen Pflanzen. 544 pp. Jena.

Kützing, F. T., I84I. Ueber Ceramium Ag. Linnaea, Bd. 15, pp. 727-46.

- 1843. Phycologia generalis oder Anatomie, Physiologie und Systemkunde der Tange. $\mathrm{xvi}+45^{8} \mathrm{pp}$. Leipzig.

- 1847. Diagnosen und Bemerkungen zu neuen oder kritischen Algen. Bot. Ztg, Bd. 5, pp. I-5, 22-5, 33-8, 52-5, 164-7, 177-80, 193-8, 219-23. 1849. Species Algarum. vi +922 pp. Leipzig.

1862. Tabulae Phycologicae, oder Abbildungen der Tange, Bd. 12, iv + 30 pp., Ioo pls. Nordhausen.

- I863. Tabulae Phycologicae,..., Bd. 13, iv +31 pp., roo pls. Nordhausen.

KyLIN, H., 1907. Studien über die Algenflora der schwedischen Westküste. iv $+288 \mathrm{pp}$. Upsala.

- I915. Úber die Blasenzellen einiger Florideen und ihre Beziehung zur Abspaltung von Jod. Ark. Bot., Bd. I4, H. 5, pp. I-I3.

- 1917. Ueber die Keimung der Florideensporen. Ark. Bot., Bd. I4, H. 22, pp. I-25.

— 1923. Studien über die Entwicklungsgeschichte der Florideen. K. svenska VetenskAkad. Handl., Bd. 63, No. II, pp. I-I39.

- 1927. Ueber die Blasenzellen der Florideen. Bot. Notiser, 1927, pp. 27585 .

- 1937. Anatomie der Rhodophyceen. In Linsbauer, K., Handb. PflAnat., Abt. 2, Bd. 6, T. 2, pp. viii + 347 .

- 1956. Die Gattungen der Rhodophyceen. xv $+673 \mathrm{pp}$. Lund.

L.akowitz, K., 1929. Die Algenflora der gesamten Östsee, viii + 474 pp. Danzig.

Lanjouw, J. 1956. International Code of Botanical Nomenclature.... 338 pp. Utrecht.

MaGnUS, P., I872. Ueber Chytridium tumefaciens n.sp. in den Wurzelhaaren von Ceramium flabelligerum und acanthonotum und andere in Meeresalgen lebende. S.B. Ges. naturf. Fr. Berl. I872, pp. 87-90.

- 1875. Die botanische Ergebnisse der Nordseefahrt von 21 Juli bis 9 Sept 1872. Wiss. Meeresuntersuch., Bd. 2, pp. 59-80.

Massart, J., I898. La cicatrisation chez les végétaux. Mém. Acad. R. Belg., Cl. Sci., T. 57 , No. I, pp. I-68.

Mazoyer, G., 1938. Les Céramiées de l'Afrique du Nord. Bull. Soc. Hist. nat. Afr. N., T. 29, pp. 317-31.

Middleton, J. T., I943. The taxonomy, host range and geographic distribution of the genus Pythium. Mem. Torrey bot. Cl., Vol. 20, No. I, pp. I-I7I.

Miranda, F., I929a. Contribuciones algologicas. Mem. Soc. esp. Hist. nat., T. 15, pp. $487-9$. 
Miranda, F., I929b. El desarollo del cistocarpio en una Ceramiácea (Ceramium flabelligerum J. Ag.). Bol. Soc. esp. Hist. nat., T. 29, pp. 47-52.

MöвıUS, M., I892. Morphologie der haartigen Organe bei den Algen. Biol. Zbl., Bd. I2, pp. 7I-87, 97-I08.

Moore, S. M., I885. Observations on the continuity of protoplasm. F. Linn. Soc. (Bot.), Vol. 2I, pp. 595-62I.

Mullahy, J. H., I952. The morphology and cytology of Lemanea australis Atk. Bull. Torrey bot. Cl., Vol. 79, pp. 393-406, 471-84.

Newton, L., I93I. A Handbook of the British Seaweeds. 478 pp. London.

OkamuRA, K., I896. Contributions to knowledge of the marine algae of Japan. II. Bot. Mag., Tokyo, Vol. 10, pp. 33-40.

Ollivier, G., I927. Sur un Ceramium à bromuques. C.R. Acad. Sci., Paris, T. I84, pp. 297-99.

— 1928. Sur les bromuques de diverses Céramiacées. C.R. Acad. Sci., Paris, T. 186, pp. 1232-4.

OltmanNs, F., I895. Notizen über die Cultur- und Lebensbedingungen der Meeresalgen. Flora, fena, Bd. 80, pp. 38-55.

- 1904. Morphologie und Biologie der Algen, Bd. I, vi+733 pp. Jena.

- 1922. Morphologie und Biologie der Algen, 2 ed., Bd. 2, iv + 439 pp. Jena.

Osterhout, W. J. V., I896. On the life-history of Rhabdonia tenera. Ann. Bot., Lond., Vol. I0, pp. 403-27.

PARKE, M. W., I953. A preliminary check-list of British marine algae. F. mar, biol. Ass. U.K., Vol. 32, pp. 497-520.

Petersen, H. E., I905. Contributions à la connaissance des Phycomycètes marins (Chytridinae Fischer). Overs. danske Vidensk. Selsk. Forh., No. 5, pp. 439-88.

1908. Danske Arter af Slaegten Ceramium (Roth) Lyngbye. K. danske vidensk. Selsk., Raekke 7, Bd. 5, pp. 4I-96.

- 1928. Nogle Jagttagelser over Cellekernerne hos Ceramium (Roth) Lyngbye. Dansk bot. Ark., Bd. 5, No. I0, pp. I-5.

PhiLlips, R. W., I897. On the development of the cystocarp in Rhodymeniales. Ann. Bot., Lond., Vol. II, pp. 347-68.

- 1926. On the form of the protoplasts in cells of the genus Ceramium and those of Dasya coccinea. New Phytol., Vol. 25, pp. 277-93.

PILGER, R., I953. Bericht über den Botanischen Garten und das Botanische Museum Berlin-Dahlem vom I März 1943 bis 31 März 1947. Mitt. bot. Gart. Mus. Berlin-Dahlem, Bd. I, pp. I-2I.

RafinesQue, C. S., I8I4. Précis des découvertes et travaux somiologiques entre 1800 et $1814 \ldots, 55$ pp. Palermo.

Reinbold, T., I906. Die Meeresalgen der deutschen Tiefsee-Expedition I898-I899. Wiss. Ergebn. 'Valdivia', Bd. 2, T. 2, pp. 55I-86.

Richards, H. M., I90I. Ceramothamnion codii, a new rhodophyceous alga. Bull. Torrey bot. Cl., Vol. 28, pp. 257-65.

Rosenvinge, L. K., I9II. Remarks on the hyaline unicellular hairs of the Florideae. Biol. Arb. til E. Warming, pp. 203-16.

- I924. The marine algae of Denmark. Vol. I. Part III. Rhodophyceae III (Ceramiales). K. danske vidensk. Selsk., Raekke 7, Bd. 7, pp. 287-486.

Rotн, A. W., I797. Catalecta botanica quibus plantae novae et minus cognitae atque illustrantur, T. I, viii + 244 pp. Leipzig.

SCHILLER, J., I9I3. Ueber Bau, Entwicklung, Keimung und Bedeutung der Parasporen der Ceramiaceen. Öst. bot. Z., Bd. 63, I44-9, 203-10.

SchmiTZ, F., 1889. Systematische Ubersicht der bisher bekannten Gattungen der Florideen. Flora, fena, 72, 435-56. 
Setchell, W. A. \& Gardner, N. L., I924. The marine algae. Expedition of the California Academy of Sciences to the Gulf of California in I921. Proc. Calif. Acad. Sci., Ser. 4, Vol. 12, pp. 695-949.

Silva, P. C., 1952. A review of nomenclatural conservation in the algae from the point of view of the type method. Univ. Calif. Publ. Bot., Vol. 25, pp. 24I324.

SONDER, W., I845. Nova algarum genera et species, quas in itinere ad oras occidentalis Novae Hollandiae collegit L. Preiss. Bot. Ztg., Bd. 3, cols. 49-57.

Sparrow, F. K., 1934. Observations on marine Phycomycetes collected in Denmark. Dansk bot. Ark., Bd. 8, No. 6, pp. I-24.

1936. Biological observations on the marine fungi of Woods Hole waters. Biol. Bull., Woods Hole, Vol. 70, pp. 236-63.

- 1943. Aquatic phycomycetes exclusive of the Saprolegniaceae and Pythium. $\mathrm{xv}+785 \mathrm{pp}$. Ann Arbor.

Stackhouse, J., 1797. Nereis Britannica; continens species omnes Fucorum in insulis Britannicis crescentum, Fasc. 2, ix-xxiv $+3 \mathrm{I}-70 \mathrm{pp}$. Bath.

ToBLER, F., I903. Beiträge zur Entwicklungsgeschichte und Biologie einiger Meeresalgen. Beih. bot. Zbl., Bd. I4, pp. I-I2.

— I906. Ueber Regeneration und Polarität sowie verwandte Wachstumsvorgänge bei Polysiphonia und anderen Algen. Fb. wiss. Bot., Bd. 42, pp. 46I-502.

Weber van Bosse, A., 1923. Liste des algues du Siboga. III. Rhodophyceae, seconde partie, Ceramiales. Siboga Exped., Monogr. 59c, pp. 312-92.

Westbrook, M. A., I930. Compsothamnion thuyoides (Smith) Schmitz. F. Bot., Lond., Vol. 68, pp. 353-64.

- 1935. Observations on nuclear structure in the Florideae. Beih. bot. Zbl., A, Bd. 53 , pp. $564-85$.

WIGgERs, F. H., I780. Primatiae florae Holsatiae, (6) + I12 + (2) pp. Kiel.

Woronichin, N. N., 1909. Die Rotalgen (Rhodophyceae) des Schwartzen Meeres. Trav. Soc. Nat. St-Pétersb., Sér. 3, T. 40, pp. 175-356.

WRIGHT, E. P., I879. On a new species of parasitic green alga belonging to the genus Chlorochytrium of Cohn. Trans. R. Irish Acad., Vol. 26, pp. 355-68. 